Vol. 5, No. 2, Oct 2016, p-ISSN: 2252-5793, hlm. 204-237

\title{
Pendidikan Jihad Menurut Imam Bukhari (STUdi NaSkah Hadits-Hadits Kitab al Jihad Dalam ShahiH BukHari)
}

\author{
Anung Al Hamat' ${ }^{1}$ Endin Mujahidin', Abas Mansur Tamam¹, Didin Hafidhuddin² \\ ${ }^{1}$ Universitas Ibn Khaldun Bogor, Indonesia \\ ${ }^{2}$ Institut Pertanian Bogor Jawa Barat, Indonesia
}

\begin{abstract}
There are two mistaken blocks in looking upon the essence of the holy war that apparently influence the religious and social life. It implies that there is a group that sees sarcastically to the terminology of the holy war even there is one that tries to eliminate from the Islamic Shari'a. On the other hand, it appears a group that behaves in extreme way and sees the holy war in narrow outlook, that is war. This is the importance of propagating the education of the holy war with the right way referring to the authoritative Islamic scholars. This research focuses on the holy war education of Imam Bukhari by studying chapters and hadiths arranged in the book of the holy war in his shahih book. So that it can be known how the idea of Imam Bukhari in the holy war education with the focus on four education components, those are goal, program, method and evaluation then how the implementation in the contemporary world of education. According to the Title of the research, so the kind of research used is the library research. The library research is a research which is carried out both with literature and non-literature. Among the samples of literature are books, notes, or the report of research from previous researches. As for the samples of non-literature, such as audio record and visual record. This research reveals the finding of the Imam Bukhari's holy war education that consists of goals those are related to the urgency of aqeedah, morals (akhlaq), the wide meaning of the holy war, and the urgency of healthe body. The Material of Aqeedah related faith, obedient, sincere, receive (tawakal), love, scare,and hope to Allah. The Materials of morals (akhlaq), such as patience, honesty, enthusiastic in doing war, courage, genorosity, keeping promise, compassionate, modesty (tawadhu'), wisdom, and avoiding evil character. The spiritual Material such as cumpolsory prayer (shalat), sunnah prayer, fasting, pray,reciting Al-Qur'an, saying takbeer, tahlil, and tasbih. The Physical Material such as keeping body hygiene, protecting and caring of body in order not to get wound, keeping physical hygiene by treating wound, keeping stamina and body hygiene by consuming good food and doing exercises before war. The methods applied are not less than 20 methods. And the evaluation by considering the quantity and the power of soldiers, security condition, preparing reserve commander, the couse of loss, joining in the holy war and administering sanctions. The ide of Imam Bukhari in the holy war education is very comprehensive, effective, and aplicative. So it is important to study his idea so that the comprehension of the holy war conception can be comprehensive and unimpaired. And
\end{abstract}


it is possible, that the thing discovered in the research would be implemented in the world of education and can be used as one of referrence in learning.

Keyword: jihad education, library research, Shahih Bukhari

\section{Pendahuluan}

Islam merupakan agama yang sempurna. Islam tidak hanya mengatur masalah kehidupan akhirat saja akan tetapi juga peduli akan kehidupan dunia. Hal ini bisa dilihat dari adanya lima (5) pilar dalam agama ini yaitu keimanan, adab, akhlak, ibadah, dan mu'amalat. ${ }^{1}$ Jika dicermati lima pilar tersebut, penulis menyimpulkan paling tidak dua pilar yang sangat erat kaitannya dengan permasalahan akhirat yaitu dengan adanya pilar keimanan dan ibadah. Adapun tiga pilar lainnya yaitu akhlak, adab dan mu'amalat sangat erat kaitannya dengan masalah dunia. Kesimpulan tersebut meskipun perlu mendapat penjelasan lebih lanjut namun yang ingin ditekankan di sini bahwa Islam merupakan agama yang sempurna dan proporsional antara urusan dunia dan akhirat.

Seiring dengan adanya lima pilar tersebut maka pendidikan islami ${ }^{2}$ sudah selayaknya mengacu kepada lima pilar tersebut. Dalam Islam, pendidikan yang unggul bukan saja hanya dilihat dari lengkapnya fasilitas pembelajaran atau diukur dengan para alumninya yang menguasai pengetahuan dan tekhnologi. Demikian juga pendidikan dalam Islam tidak saja menekankan pada aspek akal dan jasmani saja sebagaimana yang terjadi dalam pendidikan Barat. Akan tetapi hendaknya menyentuh aspek akhlak dan keimanan (ruhani).

Ungkapan tersebut selaras dengan pernyataan Ahmad Tafsir $^{3}$ ketika beliau berbicara tentang manusia dan prilakunya:

Berbicara tentang manusia yang baik berarti kita berbicara tentang budi pekerti atau akhlak. Akhlak ialah kepribadian, tingkah laku atau budi pekerti adalah sebagian dari isi kepribadian. Karena akhlak itu adalah kepribadian maka isi kurikulum pastilah mengutamakan akhlak. Bahkan akhlak itulah yang menjadi core kurikulum. Akhlak yang baik harus memiliki penjamin, penjamin terkuat adalah iman yang kuat. Modal kurikulum untuk menghasilkan lulusan yang baik yaitu lulusan yang beriman dan beramal shaleh. Amal shaleh itu berdasarkan imannya. ${ }^{4}$

Dengan demikian iman merupakan core dari manusia. Jika keimanan benar maka akan melahirkan prilaku yang benar. Jadi inti manusia adalah imannya. Untuk lebih jelasnya beliau kembali mengeluarkan pernyataan:

Manusia dikendalikan oleh world view-nya karena iman adalah sesuatu world view, maka manusia dikendalikan oleh imannya. Jadi, inti manusia adalah imannya. Karena iman itu di kalbu, maka dapat juga kita mengatakan inti manusia adalah kalbunya. Kalau begitu kalbu itulah yang menjadi sasaran pendidikan untuk diisi dengan iman. ${ }^{5}$

Demikian juga ketika beliau menjelaskan tentang karakteristik lulusan yang diharapkan, beliau menyatakan bahwa jika dirinci lebih jauh maka kita akan memiliki tiga ciri saja sebagai berikut: Pertama, badan sehat serta kuat...Kedua, otaknya cerdas serta pandai...Ketiga, lulusan mesti beriman kuat. ${ }^{6}$ 
Pernyataan yang hampir serupa juga datang dari Abuddin Nata ${ }^{7}$ yang menyatakan:

Bagi keluarga muslim, seharusnya sekolah yang dipilih bukan hanya sekolah yang hanya lulusannya unggul dalam menguasai ilmu pengetahuan, tekhnologi, keterampilan, pengalaman, melainkan juga unggul dalam kepribadian dan akhlak mulia. ${ }^{8}$

Pernyataan para tokoh tersebut selaras dengan pernyataan Abul Hasan 'Ali an Nadawî (w. 1999 M) yang menyatakan: bahwa sekolah-sekolah harus peduli dengan aspek-aspek tersebut. Sehingga melahirkan generasi-generasi (lulusan-lulusan) yang memiliki ilmu yang mumpuni, sehat akalnya, kuat fisik dan keimanannya... Sehingga dengan adanya bimbingan para guru mereka mempunyai semangat dalam beragama, siap berjuang dan berkorban dalam mengarungi kehidupan, tumbuh juga semangat persaudaraan yang tulus, kecintaan yang murni, siap membantu dan mendahulukan kepentingan orang lain. ${ }^{9}$

Kembali kepada permasalahannya bahwa pendidikan Islami adalah pendidikan yang berorientasi kepada lima pilar agama. Sehingga melahirkan manusia-manusia yang kuat imannya, benar ibadahnya, baik akhlak dan adabnya serta mampu berinteraksi dengan masyarakat dan bisa terlibat dalam kehidupan sesuai dengan skill yang dimilikinya.

Salah satu pilar agama yang disebutkan al Jazâiri adalah mu'âmalah. Dan bagian dari materi mu'âmalah yang paling terdepan dan utama sebagaimana disebutkan dalam kitabnya adalah pembahasan Jihad. ${ }^{10}$ Sehingga harus diakui bahwa jihad bukanlah kata yang asing dalam nomenklatur umat Islam. Kata jihad terpampang kuat demikian kuat dalam al-Qur'an dan hadits Nabi S.A.W.11

Jihad merupakan tonggak dan penyangga pondasi Islam bahkan ia merupakan puncak urusan Islam. Jihad merupakan cara untuk menjaga dan menolong negeri-negeri kaum muslimin dari setiap penjajahan dan penindasan, ia merupakan perisai kokoh yang bisa menjaga keberlangsungan dakwah dari gangguan moncong senjata musuhmusuh Islam, ia merupakan sarana atau alat yang bisa menjaga maqâshid as syarî̀ah sehingga agama, jiwa, harta, akal, nasab dan kehormatan bisa terlindungi.

Salah satu contohnya adalah kemerdekaan Indonesia selain berkat anugerah dari Allah kemudian juga atas semangat jihad para ulama dan rakyat Indonesia yang beriman. Indonesia dapat merdeka dan lepas dari cengkraman penjajah salah satunya adalah karena adanya ruhul jihad dalam jiwa para ulama, santri dan masyarakat Islam. Tokoh-tokoh yang tidak mau menyerahkan tanah kepada penjajah meskipun hanya sejengkal bisa terlihat dari jihad dan perlawanan Teuku Umar dan Tjut Nja Dhien dalam perang Aceh. Atau Imam Bonjol dalam perang Padri. ${ }^{12}$

Jihad merupakan bagian dari inti kekuatan kaum muslimin. Yang dengannya musuh-musuh Islam bisa merasa segan dan gentar terhadap Umat Islam. Akan pentingnya kekuatan tangan dan besi ini (jihad) Allah S.W.T telah menjelaskannya dalam Surat al Hadid ayat 25. 
Ayat tersebut menjelaskan tentang pentingnya dakwah dan mengawal dakwah tersebut dengan jihad. Dalam mengomentari potongan ayat "Dan Kami menciptakan besi yang mempunyai kekuatan hebat dan banyak manfaat bagi manusia", Ibn Katsir menyatakan:

"Dan Kami jadikan besi sebagai penangkal kalangan yang menolak dan menentang kebenaran setelah ditegakan hujjah kepadanya. Inilah sebabnya Rasulullah S.A.W menetap di Makkah selama 13 tahun setelah kenabian dan wahyu yang berupa surat-surat makkiyah diwahyukan kepadanya; isinya adalah perdebatan dengan kaum musyrik dan penjelasan akan tauhid. Tatkala hujjah sudah sampai kepada kalangan yang menyelisihi, maka Allah mensyariatkan adanya hijrah dan memerintahkan mereka berperang dengan menggunakan pedang". ${ }^{13}$

Kemudian Ibn Katsir menyitir hadits yang bersumber dari sahabat Ibn Umar: "Aku diutus dengan pedang hingga Allah saja yang disembah dan tidak ada sekutu bagiNya". 14

Jihad jika dicabut dari Umat Islam maka Umat Islam ini bagaikan harimau tanpa taring dan kuku. Tidak ditakuti dan tidak akan disegani. Sama halnya dengan negaranegara Adidaya ${ }^{15}$ seperti Amerika, Rusia dan Cina, kenapa mereka disegani dan ditakuti? Karena mereka memiliki kekuatan militer yang kuat dan tangguh sehingga akan senantiasa diperhitungkan oleh negara-negara lainnya. Wajar jika Bangsa Romawi kemudian menyatakan jika anda ingin damai maka maka siapkan militer. Diantara contoh dari bentuk damai di sini adalah dengan adanya kekuatan militer maka asset dan kekayaan Negara akan terjaga. Hal ini seperti yang dilakukan Bangsa Israel dalam rangka menjaga assetnya mereka memperkuat militernya bahkan dilengkapi dengan senjata nuklir. ${ }^{16}$ Dan secara spesifik Abdullâh bin Furaih al 'Aqlâ dalam menjelaskan tujuan pendidikan jihad beliau berpendapat adalah dalam rangka terealisasinya keamanan internal dan kemanan eksternal serta menjaga agama. ${ }^{17}$

Dalam menjelaskan urgensi jihad bagi Umat Islam, Sayyid Abdul Ghani menyatakan:

"Tidaklah suatu umat yang meninggalkan jihad dan terbuai oleh nikmatnya kehidupan dunia melainkan akan ditimpakan kehinaan dan keterpurukan. Tidak diragukan lagi dengan fenomena yang terjadi pada masa ini. Dimana kondisi kaum muslimin; darahnya ditumpahkan, hartanya dirampas, kehormatannya direnggut, tempat-tempat suci dan masjid-masjidnya dihancurkan, tanah airnya dijajah, semua ini terjadi dikarenakan cinta dunia dan takut akan kematian".18

Demikian juga akan pentingnya jihad dan relevansinya dalam menjaga maqâshid as Syarî’ah, Imam Syâtibî (w. 590 H) menyatakan:

Yang namanya jiwa harus dihormati, dijaga dan dituntut untuk bisa hidup. Sehingga kalau saja diberi pilihan antara hilangnya harta dan hidupnya jiwa maka yang harus diprioritaskan adalah bagaimana jiwa bisa hidup. Dan jika dibenturkan antara hidupnya jiwa dan matinya agama maka menghidupkan agama harus menjadi skala prioritas meskipun menyebabkan matinya jiwa. Hal ini seperti yang terjadi pada kasus jihad dalam rangka berperang melawan kaum kafir, murtad dan kalangan lainya. ${ }^{19}$ 
Oleh sebab itu jihad akan senantiasa eksis selamanya hingga hari akhir nanti. Wajar jika kemudian Abu Ja'far at Thahâwî (w. 321 H) -salah seorang tokoh Mazhab Hanafiyah- dalam matan aqidahnya menyatakan, bahwa jihad dan haji akan terus berlanjut hingga hari kiamat. ${ }^{20}$

Jihad adalah sebuah term yang memiliki dua pengertian, yaitu pengertian khusus dan pengertian umum. Yang dimaksud jihad dengan pengertian khusus adalah sebagaimana terminologi jihad menurut para ulama fikih yaitu memerangi orang kafir dalam rangka menjaga dan mempertahankan agama serta meninggikan kalimat Allah di muka bumi.

Adapun pijakan jihad dalam pengertian umum adalah dikembalikan kepada definisi jihad secara etimologis yaitu mencurahkan segenap usaha dan kemampuan dalam rangka meraih kebaikan dan kemaslahatan. Hal ini selaras dengan pernyataan Abul A'la al Maududi: "Jihad merupakan kalimat universal yang mencakup seluruh bentuk upaya dan pengorbanan."21

Atau mengacu kepada terminologi jihad menurut pernyataan Ibn Taimiyah (w. $728 \mathrm{H}$ ) yang memberikan salah satu definisi jihad dengan pengertian yang umum dan lebih luas: Jihad adalah mencurahkan segenap upaya. Yaitu kemampuan dalam meraih yang dicintai Al Haq (Allah) dan mencegah hal-hal yang Dia benci. ${ }^{22}$

Dalam ungkapan lainya beliau menyatakan: Esensi jihad adalah bersungguhsungguh mendapatkan apa yang dicintai Allah berupa keimanan dan amal shaleh serta mencegah segala yang dimurkai Allah baik berupa kekufuran, kefasikan dan kemaksiatan. $^{23}$

Demikian sudut pandang para ulama dalam melihat esensi jihad, yaitu tidak terpaku hanya pada salah satu pengertian. Akan tetapi penulis mendapatkan fakta lain dalam kehidupan masyarakat dimana kata jihad sering mendatangkan kontroversi. Ada kalangan yang hanya berkutat dengan pengertian jihad dalam arti perang dengan fisik dalam rangka membela agama. Sehingga melahirkan antithesis yaitu adanya masyarakat dalam corak lain yang alergi terhadap term jihad, memandangnya dengan sinis dan menganggapnya sesuatu yang kolot dan jumud yang harus dihapus dalam syariat Islam.

Dengan demikian, dalam tataran praktis ditemukan ada beberapa kalangan yang keliru dalam memahami jihad, yaitu adanya kalangan yang menempatkan operasi dan aksi jihad bukan pada tempatnya. Seperti melakukan pembunuhan terhadap warga sipil yang tidak bersalah dan aparat di wilayah atau negara yang aman atas nama jihad.

Di sisi lain, kemudian muncul beragam reaksi dan upaya dari berbagai kalangan untuk mereduksi makna jihad. Seolah-olah jihad hanya bermakna umum dan tidak ada sangkut pautnya dengan peperangan fisik (qital). ${ }^{24}$ Bahkan banyak kalangan yang mengusulkan untuk menghapus materi jihad dalam pendidikan. Gagasan seperti ini muncul terlebih khusus dari pihak-pihak yang anti terhadap ajaran Islam. Fenomena seperti ini telah disinggung oleh al Syantût sebagaimana dalam ungkapannya: 
Musuh-musuh Islam telah mendapatkan bahaya jihad bagi mereka. Oleh sebab itu upaya mereka fokus dalam rangka mematikan spirit jihad yang ada pada kaum muslimin. Mereka melabel kewajiban jihad merupakan sebuah ajaran ekstrim, teror dan sudah tidak selaras lagi dengan masa yang kita hidup di dalamnya. ${ }^{25}$

Kekeliruan lainnya adalah adanya kalangan yang mempunyai pandangan bahwa berhubung kondisi kaum muslimin pada hari ini dalam keadaan lemah maka tidak ada yang namanya jihad. Kemudian mereka pesimis, berpangku tangan dan menyerah dengan keadaan. Namun di sisi yang lain ditemukan juga kalangan yang memandang bahwa hari ini wajib bagi kaum muslimin untuk melakukan jihad, ayat-ayat pedang telah berlaku dan tidak mengenal istilah damai dengan orang-orang kafir atau murtad. Bagi kalangan ini yang ada adalah hanya kata perang tanpa memandang bagaimana kondisi kaum muslimin yang masih lemah dari memahami esensi jihad dan lemah dari sisi kekuatan. Kalangan ini juga tidak mau melihat adanya peluang yang luas dalam pendidikan dan dakwah Islam yang masih bisa dioptimalkan secara maksimal.

Tidak dipungkiri bahwa jihad merupakan suatu kata yang mengandung dua pengertian yaitu umum dan khusus. Sebagaimana bisa ditemukan dalam al-Qur'an dan hadits. ${ }^{26}$ Sehingga menjadi sebuah kekeliruan jika menghilangkan salah satu esensi dari makna jihad yaitu perang (berjuang) dalam rangka membela agama Allah baik dengan harta maupun dengan jiwa.

Dalam mendefinisikan beberapa makna jihad, Badan Pembinaan dan Pengembangan Bahasa Kementrian Pendidikan dan Kebudayaan sendiri menyatakan:

Kata jihad berasal dari bahasa Arab, yaitu aljihad, yang berarti 'per-juangan'. Dalam bahasa Indonesia, kata jihad digunakan dengan pengertian sebagai berikut. Jihad ialah usaha yang dilakukan dengan sungguh-sungguh untuk mencapai kebaikan manusia secara keseluruhan. Contoh kalimat yang menggunakan kata jihad dengan makna seperti itu adalah sebagai berikut: (1) Kita berjihad melawan kemiskinan. (2) Demi ketenteraman batin Anda, berjihadlah melawan hawa nafsu. Makna jihad yang lain ialah perjuangan membela agama dengan cara mengorbankan harta benda, jiwa, dan raga. Contoh kalimat yang mengandung kata jihad dengan pengertian itu adalah sebagai berikut. (3) Orang yang berjihad di jalan Allah adalah orang yang berjiwa mulia.

Ketika para ulama dan fuqaha memasukan pembahasan jihad dalam buku-buku klasik mereka baik berupa buku fikih, tafsir, akidah maupun hadits, yang kemudian mereka menjelaskan tentang beragam keutamaan, dalil-dalilnya dan beragama permasalahannya adalah dalam tema jihad dengan makna qitâl; berperang melawan musuh secara fisik.

Jihad dengan makna qitâl (perang) inilah yang dikawatirkan oleh kalangan anti Islam. Sehingga mereka berusaha untuk mengalihkan makna spesifik jihad dari jiwa dan semangat Umat Islam, dengan melontarkan tuduhan yang dianggap tepat pada situasi dan kondisi tertentu.

Sebagai contoh adalah apa yang digambarkan dalam pengantar penerbit buku Jihad Fî Sabîlillâh: 
Umat Islam Indonesia pernah dilempari tuduhan istilah "Komando Jihad" sekitar tahun 1980. Maka pada bulan April 1981, antara pihak pemerintah yang diwakili oleh Menteri Agama, H. Alamsyah Ratu Perwiranegara, Pangkopkamtib Laksamana Sudomo, Pangkowilhan-Pangkowilhan, Panglima-Panglima Daerah, LaksusdaLaksusda dan lain-lain dengan tokoh-tokoh Islam antara lain Prof. Dr. Hamka, H. Hasan Basri, K.H. Syukri Ghazali, K.H. Masykur, Imran Rasyidi. SH, Nuruddin Lubis, Prof. Dr. H.M Rasyidi, H.M. Yunan Nasution, H. Bukhari Tamam, H. Prodjokusumo, H. Soleh Iskandar, Ny. K.H. Wahid Hasyim, Ny. Rohana ZA Ahmad, Ny. Aisyah Amini. SH, dan sejumlah tokoh-tokoh Islam lainnya, merumuskan tujuh (7) point yang disepakati, diantaranya, istilah "Komando Jihad" untuk seterusnya disetujui tidak digunakan lagi, karena ini akan lebih mencemarkan agama Islam. ${ }^{27}$

Diantara kalangan yang merasa kawatir terhadap makna jihad secara spesifik adalah yang dilakukan kalangan Barat dan sekutunya yang meminta Negara Pakistan untuk menghilangkan ayat-ayat jihad dalam pendidikan dan kurikulum pendidikan. Tentunya hal ini menuai kritik bukan saja dari kalangan islamis akan tetapi kritikan datang juga dari kalangan sekuler Pakistan. Berikut ini adalah bagian dari liputan seputar reaksi rakyat Pakistan sebagaimana yang telah dimuat oleh salah satu situs:

Penghilangan ayat ayat jihad dari al-Qur'an yang mulia kedalam kurikulum pengajaran sekolah oleh pemerintah koalisi di barat laut Provinsi Khyber Pakhtunkhawa, yang berbatasan dengan Afghanistan, telah mengundang kemarahan dari kalangan sekuler.

"Jika semua mitra koalisi memiliki suara bulat menyetujui penghilangan ayat ayat jihad dalam kurikulum sekolah adalah kelalaian dan mereka tidak punya tujuan lain kecuali hanya untuk menyenangkan para tuan asingnya," Hashmatullah Khan mengatakan, seorang menteri provinsi mewakili Jamat-e-Islami.

"Kami tidak akan mendesain kurikulum kami pada arahan atau pedoman negara asing dan negara donor," Hashmatullah menambahkan.

"Setiap ayat dari al-Quran yang mulia adalah sama pentingnya. Jika maksud di balik motif penghilangan ayat ayat jihad dalam kurikulum hanyalah karena untuk mengurangi tekanan Barat, berarti kita memberikan pengertian yang salah tafsir kepada mereka tentang Jihad", "Bahkan, penghilangan ayat (tentang Jihad) karena tekanan barat akan menyebabkan para pemuda rentan terhadap propaganda Barat," pikirnya.

Hashmatullah mengatakan bahwa pihaknya tidak akan berkompromi dalam masalah ini. "Ini adalah salah satu bagian dari upaya kami untuk memperkenalkan salah satu kurikulum di seluruh provinsi, yang belum pernah terjadi dalam sejarah. Lawan kami harus bergandengan tangan dengan kami dan bukan hanya mencetak celah untuk menyenangkan pihak asing, "katanya. ${ }^{28}$

Salah satu kampus ternama dan tertua, Al Azhar pun tidak luput dari tekanan pihak asing untuk menghapus materi-materi yang berkaitan dengan jihad. Demikian juga dengan Negara Saudi. Dimana Mesir dan Saudi merupakan dua negara yang paling banyak memasok para pejuang untuk membela kaum muslimin. Salah satu situs perhimpunan mahasiswa Mesir memaparkan:

Al-Azhar sendiripun juga sering ditekan dalam materi-materi pendidikan dengan penghapusan materi jihad dalam bangku perkuliahan, di Arab Saudi para Khatib 
Haramain dan Nabawi ketika musim haji lebih ditekankan pada perbuatan menabung amalan sendiri dan jarang sekali menyinggung permasalahan umat, dan kalaupun ada hanya sebatas dan sekedarnya saja, hal yang sangat ironis sekali. ${ }^{29}$

Jihad yang merupakan puncak urusan Islam yang paling tinggi adalah bagian dari agama Islam yang tidak bisa dipisahkan dari agama ini. Ia merupakan amalan yang paling utama setelah melaksanakan farâidh. Demikian yang dinyatakan Ibn Rajab al Hanbali (w. 795 H) dengan menisbatkan pendapatnya kepada Imam Ahmad bin Hanbal (w. $241 \mathrm{H}$ ).

Dalam sejarah tercatat ada beberapa kalangan yang berusaha ingin menghilangkan ajaran jihad dalam dunia pendidikan secara khusus dan dalam agama Islam secara umum. Diantaranya adalah Ahmad Khan (w. 1898 M) seorang keturunan muslim India. Gagasan-gagasannya dikemudian hari banyak diadopsi oleh aliran Ahmadiyah Qadiyaniyah. ${ }^{30}$ Diantara ideologinya adalah menghilangkan dan menghapus ajaran jihad. ${ }^{31}$

Begitu juga dengan sosok Thaha Husain (w. 1973 H) yang dikenal dengan sosok penggagas Gerakan Pembaharuan Sastra Arab. Diantara pernyataannya yang cukup ganjil -sebagaimana yang diungkapkan oleh salah seorang guru besar Al Azhar Cairo 'Ali Syâhîn - adalah bahwa jihadnya para sahabat Rasulullah S.A.W di Mesir merupakan bagian dari bentuk kolonialisme. Tidak ada bedanya dengan bangsa Romawi dan Persia. $^{32}$

Hal yang sama dilakukan oleh Musthafa Kamal at Tatruk (w. 1938 H) yang diklaim oleh sebagian kalangan sebagai pembaharu Islam. Selain dia menghapus ajaran jihad, 'Ali Syâhîn menggambarkan dengan sosok yang telah merobohkan sendi-sendi Khilafah Islamiyah di Turki, mengganti bahasa Arab dengan bahasa Latin dalam penulisan mushaf, menghapus undang-undang ahwâl syakhsyiyah, mengharamkan poligami, menghapus hukum waris dengan menyamakan bagian laki-kali dan perempuan, melarang pakaian busana muslimah, memproduksi khamar dan memerintahkan para remaja putri untuk pergi ke klub-klub malam, membolehkan wanita muslimah menikah dengan laki-laki non muslim dan lain-lain. ${ }^{33}$

Ditambah lagi yang datang dari kalangan non Islam diantaranya adalah yang dilontarkan oleh seorang orientalis A.J. Wensinck dalam bukunya The Muslim Creed: Its Genesis and Historical Develepment.34 Yang kemudian oleh Ahmad Ghurab diterjemahkan ke dalam Bahasa Arab dengan judul al 'Aqîdah al Islâmiyah: Nasy'atuhâ wa Tathawwuruhâ al Târîkhî. Dalam bukunya tersebut, A.J. Wensinck menyatakan bahwa jihad merupakan ajaran baru yang datang setelah abad ke $2 \mathrm{H}$. Padahal dalil-dalil tentang jihad sudah tertuang baik dalam al-Qur'an maupun Sunnah Rasulullah S.A.W.35

Pendidikan jihad merupakan tahapan yang pernah dilalui oleh Rasulullah S.A.W. Salah seorang intelektual Islam, 'Ali Juraisyah (w. 2011 M) menyatakan:

Dengan melihat sekilas perjalanan manusia terbaik dan suri tauladan manusia, Muhammad S.A.W maka kita mendapatkan bahwa dalam berdakwahnya beliau menempuh tiga jalan. Atau dalam ungkapan lain melakukan 3 tahapan: 1) menyebarkan dakwah, 2) melakukan tarbiyah dan pembentukan (kaderisasi), 3) 
melakukan konfrontasi fisik (jihad) sehingga meraih kemenangan....Pendidikan militer atau pendidikan militer Islam (atau tarbiyah jihadiyah-pen) merupakan bagian dari pilar pendidikan yang benar (at Tarbiyah as Shahihah)...jika kita telah mengetahui bahwa seorang muslim mempunyai akal, ruh dan jasad. Maka dalam konsep pendidikan yang benar yaitu pendidikan dimulai dari akal kemudian melewati ruh dan berakhir di jasad. Dengan demikian merupakan perkara yang penting seorang muslim siap melakukan jihad di jalan Allah dengan harta dan jiwanya serta memahami urgensitas jihad dan komitmennya terhadap Umat Islam. ${ }^{36}$

Amin Rais ${ }^{37}$ termasuk yang merasa resah dengan memudarnya semangat dan ruh jihad. Dalam pandangan beliau Islam tidak cukup hanya dengan melaksanakan shalat, puasa dan ibadah lainnya sementara ajaran jihad ditinggalkan.

Harian Umum Pelita menurunkan berita seputar ceramah Amin Rais dengan tema 'Hidupkan Kembali Semangat Jihad':

Amin Rais menghimbau warga Muhammadiyah untuk menghidupkan kembali semangat jihad (ruhul jihad). Semangat jihad harus diinjeksi kembali agar mempercepat tujuan Muhammadiyah. Amin Rais menyampaikan saat pengajian yang diselenggarakan Majelis Tabligh dan Dakwah Khusus (MTDK) PP Muhammadiyah, Sabtu (11/4), di Pusat Dakwah Muhammadiyah, Jakarta.

Menurut Amin, perjalanan Persyarikatan Muhammadiyah yang mendekati satu abad ini merupakan prestasi gemilang. Apalagi pertumbuhan jumlah amal usaha dalam bentuk sekolah, perguruan tinggi, rumah sakit, dan panti asuhan terus meningkat. Tapi Amin menyayangkan semangat jihad sepertinya agak memudar. Hidupkan Kembali Semangat Jihad. ${ }^{38}$

Begitu juga pernyatan ketika beliau berada di hadapan para kader Muhammadiyah Yogya, dalam acara "Rapat Kerja dan Dialog Pengkaderan" tanggal 2324 Februari 2013:

Bahkan saya sering mengatakan, bahwa Muhammadiyah itu diam-diam juga mempraktikkan bid'ah. Kita sering mengatakan NU bid'ah, tapi kita kadang-kadang tidak terasa juga bid'ah, cuma bid'ah mengurangi (al ibdtida'u bil nuqshan). Dimana pengurangannya? Kita tidak sadar, kita tidak tahu, karena kita merasa tidak pernah melakukannya.

Tapi lihat dalam training-training Muhammadiyah atau Aisyiyah, atau di beberapa even Muhammadiyah, hampir jarang dibahas atau didorong tentang konsep alQuranyang namanya Al Jihad. Kita itu sepertinya dengan konsep jihad, kalau alergi tidak, cuma sudah cukupkah jihad itu dengan teologi $\mathrm{Al} M \mathrm{Ma}^{\prime} u n$.

Sejak saya kecil $A l M a^{\prime} u n$, saya di IMM $A l M a^{\prime} u n$, saya jadi ketua PP Muhammadiyah $A l M a^{\prime} u n$, dan sampai sekarang Alhamdulillah juga masih tetap Al Ma'un. Itu betul dan tidak salah.

Teori Al Ma'un itu tetap, tapi harus kita tambah lagi, karena yang namanya jihad itu jumlahnya sebanyak kata zakat. Kenapa kita berani membicarakan soal zakat dan lain-lain, tetapi soal jihad itu tidak pernah kita ucapkan. (Kutipan, hal. 20). ${ }^{39}$ 
Akan urgensitas pendidikan jihad ini, para menteri pendidikan negara-negara Arab mengadakan konfrensi yang diselenggarakan di Kuwait pada tahun 1968. Diantara salah satu keputusannya adalah:

Bahwa konfrensi ini perlu meninjau ulang kurikulum pendidikan Bangsa Arab setelah terjadinya peristiwa 5 Juni (tahun 1967). Sehingga kita meyakini bahwa kita benar-benar membutuhkan adanya pendidikan spiritual, akhlak dan militer yang praktis dalam rangka menanamkan keimanan dan spirit jihad, pengorbanan serta menjadikan gugur di jalan Allah dalam rangka membela negara dan umat merupakan sesuatu yang paling bernilai dan tujuan yang paling mulia. ${ }^{40}$

Begitu juga dengan yang dilakukan Jenderal Muhammad Jamaluddin -Direktur Bimbingan Mental Angkatan Bersenjata Mesir- setelah perang Juni 1967 menetapkan kurikulum yang muatannya berisi reedukasi mental dan spiritual prajurit dengan dasar Islam. Diantara poin-poinnya:

Pertama, menjadikan jihad di jalan Allah sebagai ideologi perang dalam tubuh tentara Mesir.

Kedua, jargon 'Menang atau Syahid' sebagai syi'ar resmi dalam tentara Mesir.

Ketiga, menjadikan suara takbir 'Allahu Akbar' sebagai suara teriakan resmi para tentara baik ketika mereka menyerbu, menyebrangi jalanan, gerakan mereka dan dalam kondisi lainnya... ${ }^{41}$

Demikian juga dengan komentar Sayyid Qutub atas firman Allah dalam Surat al Anfal ayat 60. Dimana beliau menyatakan bahwa persiapan jihad merupakan kewajiban yang mengiringi wajibnya jihad. Redaksi ayat jelas memerintahkan untuk mempersiapkan kekuatan dengan beragam bentuk dan jenis kekuatan. Adapun ayat tersebut menyebutkan secara khusus kuda yang ditambat karena pada masa itu (kuda) merupakan sarana yang paling menonjol....Islam harus mempunyai kekuatan yang dengannya bisa membebaskan perbudakan manusia. Dan yang pertama dibuat oleh ayat ini adalah: 1) Memberikan jaminan keamanan kepada kalangan yang telah meyakini akidah ini sehingga mereka aman. 2) Memberikan rasa takut kepada musuhmusuh agama sehingga tidak terdetik dalam pikiran mereka untuk mengganggu Negara Islam. 3) Memberikan rasa takut kepada musuh-musuh agama sehingga tidak terdetik dalam pikiran mereka menghentikan penyebaran Islam di muka bumi. Dan dari situlah kemudian terjadi pembebasan manusia di muka bumi. 4) Menghancurkan seluruh kekuatan di muka bumi yang merampas hak uluhiyah Allah. ${ }^{42}$

Dari penjelasan di atas maka tidak diragukan lagi bahwa pendidikan jihad merupakan bagian penting dari pendidikan Islam. ${ }^{43}$ Bahkan Abdullâh Nâshih Ulwân (w. 1987 M) membuat pembahasan khusus di akhir pembahasan kitabnya yang menekankan pentingnya pendidikan jihad. Dimana beliau membuat 'Pasal Ketiga: Beberapa Saran Seputar Pendidikan Yang Harus Dilakukan'. Diantara yang beliau sarankan adalah, pentingnya menanamkan ruhul jihad dalam jiwa anak. ${ }^{44}$

Dan secara eksplisit akan kita temukan juga tentang pentingnya pendidikan jihad ini dari pernyataan Khâlid al Hâzimî ketika mendeskripsikan urgensi pendidikan dalam aspek fisik dan tujuan dari pendidikan fisik. ${ }^{45}$ 
Demikian juga dengan para ulama klasik dalam beragam disiplin ilmunya telah menjadikan tema jihad sebagai bahasan yang tidak terpisahkan dalam karya-karya mereka baik dalam masalah tafsir, akidah, hadits maupun fikih.

Diantara deretan ulama hadits yang paling pertama memasukan pembahasan jihad dalam karyanya adalah Muhammad Ismail al Bukhari (w. $256 \mathrm{H}$ ), yaitu dalam kitab al Jami' as Shahihnya. ${ }^{46}$ Banyak kalangan yang menjadikan kitab hadits beliau sebagai referensi dalam pengambilan dalil. Hal ini dikarenakan kitab beliau merupakan kitab yang paling ketat dalam penyeleksian hadits. Sehingga para ulama menyebutnya dengan ashahhul kutub ba'da al-Qur'ân Shahîhul Bukhârî (kitab yang paling valid setelah al-Qur'an adalah Shahih al Bukhari). Hal ini senada dengan pernyataan Imam Nawawi (w. $676 \mathrm{H}$ ) yang menyatakan bahwa Shahih Bukhari dan Muslim merupakan kitab yang paling valid setelah al-Qur'an, dan diantara keduanya Bukhari yang paling valid dan paling banyak manfaatnya. ${ }^{47}$

Abu Zahwût ${ }^{48}$ menukil pendapat Imam Dzahabi (w. 748 H) yang menyatakan bahwa adapun Jami' al Bukhari as Shahih merupakan kitab Islam yang paling agung dan paling mulia setelah kitab Allah ta'ala. ${ }^{49}$

Sehubungan Imam Bukhari merupakan ulama hadits pertama yang meletakan hadits-hadits seputar jihad secara sistematis dalam kitab Shahihnya, maka sudah selayaknya pendidikan jihad dalam Kitab Jihad wa Siyar Shahih Bukhari perlu dikaji dan diteliti dalam bentuk penelitian disertasi.

\section{Metodologi}

Penelitian ini merupakan jenis penelitian library research (riset kepustakaan). Dimana library research sendiri merupakan salah satu metode dari pendekatan kualitatif. ${ }^{50}$ Jenis penelitian library research adalah penelitian yang dilaksanakan dengan menggunakan literatur (kepustakaan). Penelitian kajian pustaka ini merupakan proses kegiatan menelaah dan membaca bahan-bahan pustaka, seperti buku-buku atau dokumen-dokumen. 51

Kalangan lain mengungkapkan dengan sedikit tambahan bahwa library research adalah penelitian yang dilaksanakan dengan menggunakan literatur dan non literatur. Diantara contoh literatur yaitu berupa buku, catatan, maupun laporan hasil penelitian dari penelitian terdahulu, ${ }^{52}$ jurnal, majalah ilmiah, surat kabar, hasil-hasil seminar, artikel-artikel ilmiah yang belum dipublikasi, narasumber dan surat-surat keputusan. ${ }^{53}$ Adapun contoh dari non literatur seperti rekaman audio dan audio visual. ${ }^{54}$

Sesuai dengan definisi library research maka sumber data dalam penelitian ini adalah dengan melakukan studi pustaka. Yaitu teknik pengumpulan data yang dilakukan dengan mempelajari buku-buku referensi, laporan-laporan, majalah-majalah, jurnal-jurnal, internet (web) dan media lainnya yang berkaitan dengan obyek penelitian.

Studi kepustakaan merupakan langkah yang sangat penting dalam penelitian. Studi kepustakaan sangat diperlukan dalam beberapa kondisi diantaranya ketika 
mengidentifikasi masalah, hasil-hasil penelitian terdahulu dan dokumen-dokumen berkaitan dengan data dan informasi tentang suatu penelitian, diperlukan dalam merumuskan masalah atau memetakan variabel-variabel atau aspek-aspek yang berhubungan dengan fokus masalah dan dalam mencari serta memilih teori yang cocok, yang bisa memperkuat rumusan masalah dan sangat diperlukan dalam menyusun landasan teoritis yang mendasari keseluruhan kerangka pikir dan kerangka kerja dari penelitian. ${ }^{55}$

Karena penelitian ini termasuk katagori riset kepustakaan, maka dalam hal ini penelitian akan menggunakan sumber data literatur dan non literatur seperti rekaman audio dan audio visual. ${ }^{56}$ Adapun sumber data di sini terbagi kedalam dua pembagian, yaitu:

a. Sumber data primer, yaitu seluruh bab dan hadits yang ada dalam Kitab Jihad wa Siyar Shahih Bukhari yang terdiri dari 199 bab dan 376 hadits dengan pengulangan (sementara jika tanpa diulang ada 110 hadits).

b. Sumber data sekunder, yaitu penjelasan-penjelasan hadits (syarah hadits) yang dilakukan para ulama atas bab dan hadits kitab Jihad wa Siyar, hasil-hasil penelitian dari karya-karya para ulama klasik dan kontemporer serta rekaman ceramah audio dan audio visual yang dipandang relevan dengan pembahasan ini. ${ }^{57}$

Teknik pengumpulan data yang digunakan dalam penelitian ini adalah pengumpulan data literer dan non literer yaitu dengan mengumpulkan bahan-bahan pustaka yang berkesinambungan (koheren) dengan objek pembahasan yang diteliti. Data yang ada dalam kepustakaan tersebut dikumpulkan, diolah dan dianalisis dengan cara:

a. Editing, yaitu pemeriksaan kembali dari data-data yang diperoleh terutama dari segi kelengkapan, kejelasan makna dan koherensi makna antara yang satu dengan yang lain.

b. Organizing yakni menyusun data-data yang diperoleh dengan kerangka yang sudah ditentukan.

c. Penemuan hasil penelitian, yakni melakukan analisis lanjutan terhadap hasil penyusunan data dengan menggunakan kaidah-kaidah, teori dan metode yang telah ditentukan sehingga diperoleh kesimpulan (inferensi) tertentu yang merupakan hasil jawaban dari rumusan masalah. ${ }^{58}$

\section{HaSil dan PEMBahasan}

Diantara pengertian implementasi secara etimologis sebagaimana disebutkan dalam beberapa kamus adalah pelaksanaan atau penerapan. ${ }^{59}$ Adapun secara terminologis adalah sebagaimana yang dipaparkan Nurdin Usman dalam bukunya yang berjudul Konteks Implementasi Berbasis Kurikulum (Usman, 2002:70) dikemukakan bahwa implementasi adalah bermuara pada aktivitas, aksi, tindakan, atau adanya 
mekanisme suatu sistem. Implementasi bukan sekedar aktivitas, tetapi suatu kegiatan yang terencana dan untuk mencapai tujuan kegiatan.

Sementara Hanifah Harsono dalam bukunya yang berjudul Implementasi Kebijakan dan Politik (2002:67) dikemukakan bahwa implementasi adalah suatu proses untuk melaksanakan kebijakan menjadi tindakan kebijakan dari politik ke dalam administrasi. Pengembangan kebijakan dalam rangka penyempurnaan suatu program. ${ }^{60}$

Kaitannya dengan implementasi pendidikan jihad dalam kitab Jihad wa Siyar Shahih Bukhari dalam dunia pendidikan Islam bisa dilihat dalam pembahasan poin-poin berikut:

\section{A. Implementasi Tujuan Pendidikan Jihad Dalam Kitab Jihad Wa Siyar Dalam Pendidikan Islam}

Sebagaimana sudah dirumuskan dalam Bab IV bahwa tujuan pendidikan jihad dalam kitab Jihad wa Siyar Shahih Bukhari paling tidak dirumuskan dalam enam poin sebagai berikut:

1. Memiliki keimanan dan keikhlasan sebagai landasan amal

2. Memiliki akhlak yang mulia

3. Memiliki spiritualitas yang baik

4. Memiliki pemahaman tentang hakikat jihad

5. Memiliki fisik yang sehat dan kuat

6. Memiliki kesiapan untuk berjihad

Jika dicermati seluruh poin dari tujuan pendidikan jihad yang ada dalam kitab Jihad wa Siyar, sebenarnya selaras dengan tujuan pendidikan secara umum yaitu menjadikan manusia terbaik. ${ }^{61}$ Adapun implementasinya dalam pendidikan Islam dapat dilihat dalam penjelasan berikut:

\section{Memiliki keimanan yang kuat dan keikhlasan dalam beramal}

Hendaknya murid atau lulusan memiliki keimanan yang kuat dan hendaknya ikhlas dalam beramal karena Allah. Sehingga ketika berjuang tidak ada yang mendasari perjuangannya dan seluruh aktifitasnya kecuali karena iman kepada Allah dan membenarkan janji Rasul-Nya serta mengharap ridha Allah S.W.T.

Pentingnya keimanan dalam seluruh aktivitas adalah selaras juga dengan pernyataan Ahmad Tafsir yang menyatakan:

Lulusan mesti beriman kuat. Sulit dibayangkan seseorang akan mudah hidup tenang bila ia tidak beriman. Mungkin saja banyak kesulitan yang dihadapinya tidak mengganggunya bila masalah itu dapat ia rasionalkan, dapat diselesaikan dengan IQ-nya yang tinggi. Tetapi akan banyak masalah yang pasti ia tidak akan mampu merasionalkannya. Nah, pada bagian inilah ia memerlukan iman yang kuat. ${ }^{62}$

\section{Memiliki akhlak yang mulia}


Seorang murid yang siap berjuang di jalan Allah sudah seharusnya menghiasi dirinya dengan akhlak yang mulia dan budi pekerti yang terpuji. Diantara sifat atau akhlak terpuji adalah kejujuran. Rumusan ini selaras dengan pernyataan Ahmad Tafsir yang menyatakan:

Sifat ini merupakan salah satu turunan dari hati yang penuh iman. jujur barulah terwujud bila orang mampu jujur terhadap dirinya sendiri; seseorang mampu jujur terhadap orang lain belumlah dapat dijadikan jaminan bahwa ia jujur...Kejujuran amat diperlukan dalam kehidupan yang penuh persaingan. Orang yang tidak jujur dapat dipastikan akan tersingkir dalam persaingan itu.63

Dengan akhlak yang terpuji akan mendapatkan simpatik dan dukungan dari masyarakat. Namun sebaliknya jika pelaku jihad memiliki akhlak dan prilaku yang tercela maka akan tersingkir dari dukungan dan hati masyarakat. Hal ini sebagaimana yang dinyatakan Abdullah Azzam:

Pendidikan (termasuk pendidikan akhlak di dalamnya) merupakan skala prioritas sebelum seseorang memegang senjata. Tanpa pendidikan maka orang-orang yang membawa senjata itu bagaikan gerombolan bersenjata yang mengancam keamanan warga serta menakutkan mereka siang dan malam. Hal ini bisa anda bandingkan antara komandan yang terdidik dengan komandan yang tidak terdidik yang masing-masing menguasai satu wilayah. Akan ditemukan satu wilayah dalam keadaan tenang dan nyaman sementara wilayah yang lainnya justru mencekam dan banyak masyarakat yang mengeluh. 64

\section{Memiliki spiritualitas yang baik}

Aspek spiritual merupakan salah satu faktor penting dalam pendidikan Islam. Wawasan yang luas dan fisik yang sehat akan menjadi tidak ada nilainya dan akan menjadi keropos tatkala tidak memiliki spiritualitas yang baik. Seorang muslim yang memiliki spiritulitas yang baik akan senantiasa terpaut hatinya dengan Allah dikarenakan dia memiliki hubungan yang erat dengan sang pencipta. Bagian dari program aspek spiritual seperti shalat, membaca al-Qur'an dan berzikir kepada Allah bisa menjadikan seorang senantiasa menjaga dirinya dan senantiasa merasa dimonitor oleh Allah. Ketika seseorang sudah merasa dimonitor oleh Allah maka dia tidak akan terbawa hanyut oleh rusaknya kehidupan dunia, akan senantiasa mampu menahan jiwa dan syahwatnya. ${ }^{65}$

\section{Memiliki pemahaman tentang hakikat jihad}

Memiliki pemahaman tentang hakikat jihad bisa diimplementasikan dalam pendidikan Islam bahwa kehidupan di dunia hanya sementara dan hati seorang hamba tidak terpaut dengan kenikmatan dunia hingga melupakan amalan yang paling utama yaitu berjuang di jalan Allah. Demikian juga jihad yang dilakukan bukan dalam rangka mendapatkan dunia atau ganimah, bukan karena fanatisme golongan dan kesukuan akan tetapi dalam rangka menegakan kalimat Allah di muka bumi dan dalam rangka mengembalikan kemulian Islam dan kaum muslimin. 
Seorang muslim juga harus memahami bahwa jihad dalam arti perang harus ditopang dan diiringi dengan bentuk jihad lainnya seperti belajar untuk mendapatkan wawasan dan pengetahuan, menyebarkan ilmu, mampu berinteraksi dengan masyarakat, menguasai media massa, dan penunjang-penunjang jihad lainnya.

\section{Memiliki fisik yang sehat dan kuat}

Dalam menjelaskan terminologi dan urgensi sehat dan kuat, Ahmad Tafsir menyatakan bahwa sehat ialah tidak sakit. Jelasnya tidak penyakitan. Ini diperlukan agar tenang dan mampu produktif. Kuat ialah kemampuan otot dan non otot dalam menyelesaikan pekerjaan. Ini penting agar berproduksi maksimal. ${ }^{66}$

Dengan demikian fisik yang sehat dan kuat sangat penting bagi seorang muslim. Hal ini selaras dengan pernyataan Ahmad Tafsir dalam bukunya yang lain, dimana beliau menyatakan bahwa seorang muslim perlu memiliki jasmani yang sehat dan kuat, terutama berhubungan dengan keperluan penyiaran dan pembelaan serta penegakan ajaran Islam. Dilihat dari sudut ini maka Islam mengidealkan Muslim yang sehat serta kuat jasmaninya. ${ }^{67}$

Rumusan tujuan pendidikan tersebut sudah sesuai juga dengan pasal 3 UU No.20/2003 yang menyatakan bahwa 'Pendidikan nasional...bertujuan untuk berkembangnya potensi peserta didik agar menjadi manusia yang beriman dan bertaqwa kepada Tuhan Yang Maha Esa, berakhlak mulia, sehat, berilmu,...68

\section{Memiliki kesiapan untuk berjihad}

Memiliki kesiapan untuk berjihad dapat diimplementasikan dalam pendidikan bahwa setiap muslim harus terdetik dalam jiwanya ingin membela agama Allah baik dengan ilmunya, harta dan bahkan jiwanya. Diantara bagian dari bentuk kesiapan tersebut adalah dengan menuntut ilmu yang benar dan bermanfaat, menyadarkan masyarakat akan pentingnya berjuang di jalan Allah, melakukan persiapan baik persiapan dalam bentuk materi maupun fisik. Hal ini sesuai dengan firman Allah dalam Surat al Anfal ayat 60.

\section{B. Implementasi}

Sebagaimana sudah dijelaskan dalam pembahasan sebelumnya bahwa program harus sesuai dengan tujuan yang sudah dirumuskan, yaitu dalam rangka menjadikan manusia terbaik. Maka implementasi dari program pendidikan jihad dalam kitab Jihad wa Siyar bisa dilihat dalam enam program, diantaranya program dalam aspek keimanan, aspek akhlak, aspek spiritual, aspek pemahaman tentang hakikat jihad, aspek jasmani dan aspek kesiapan. Adapun penjelasannya atas implementasi dari poin-poin tersebut bisa dilihat dalam pembahasan berikut:

\section{Aspek Keimanan}

Dalam tujuan pendidikan jihad dalam kitab Jihad wa Siyar dalam aspek keimanan disebutkan pemahaman tentang urgensi keimanan dan keikhlasan sebagai landasan dan pilar amal. Kemudian diantara programnya dalam rangka merealisasikan tujuan tersebut adalah mengajarkan materi seputar iman kepada Allah, ikhlas dalam beramal, 
memberikan kecintaan kepada Allah, ta'at kepada Allah, tawakal kepada Allah dan berharap mendapatkan rahmat Allah. Adapun implementasinya dalam pendidikan Islam adalah:

a. Ikhlas dalam berjihad. Ikhlas merupakan ruhnya amal, maka jihad yang dilakukan adalah hendaknya ikhlas karena Allah bukan karena mencari dunia, atau ingin disebut sebagai sosok pemberani atau agar dikenang sebagai pahlawan.

b. Memberikan loyalitas kepada Allah dan Rasul-Nya. Maksudnya adalah hendaknya murid mencintai apa yang dicintai Allah dan Rasul-Nya serta membenci apa yang dibenci oleh Allah dan Rasul-Nya. Demikian juga mencintai setiap orang yang cinta kepada Allah dan Rasul-Nya serta membenci orang yang benci kepada Allah dan Rasul-Nya. Dalam pengertian ini, jihad merupakan bagian dari yang dicintai Allah dan Rasul-Nya, maka seorang muslim harus mencintai jihad. Demikian juga bagian dari yang dibenci Allah adalah Allah membenci orang kafir dan munafik maka seorang muslim harus membenci mereka karena Allah.69

c. Ta'at. Hendaknya seorang muslim atau murid senantiasa ta'at kepada Allah dan Rasul-Nya secara mutlak. Demikian juga mentaati pemimpin atau komandan selama dia memerintahkan kebaikan dan ketaatan bukan memerintahkan untuk melakukan kemaksiatan. Karena tidak boleh mendengar dan taat dalam hal bermaksiat kepada Allah.

d. Tawakkal kepada Allah. Dalam menghadapi peperangan dengan musuh hendaknya seorang mujahid melakukan segala bentuk persiapan dengan menyiapkan hal-hal yang bisa mendatangkan kemenangan dan menghindarkan atau meminimalisir beragam faktor yang bisa menyebabkan kekalahan lalu kemudian menyerahkan urusannya kepada Allah dengan bertawakkal kepada-Nya.

e. Berharap. Seorang mujahid hendaknya menjadikan Allah sebagai tempat tumpuan harapannya. Dalam menghadapi musuh tidak ada yang diharapkannya kecuali kemenangan dengan membawa pahala dan ganimah. Atau kalaupun harus gugur maka dia berharap menjadi syahid. Ringkasnya dia akan berharap hidup mulia atau mati syahid.

Seluruh program tersebut sangat perlu untuk dirancang sehingga akan melahirkan muslim atau murid dan lulusan-lulusan yang mempunyai keimanan yang kuat.

\section{Aspek Akhlak}

Program pendidikan jihad dalam kitab Jihad wa Siyar dalam aspek akhlak adalah mengajarkan dan menanamkan sifat sabar, jujur, antusias dalam berperang, berani, dermawan, menepati janji, penyayang, tawadhu', bijak, dan menghindari sifat-sifat tercela. Adapun implementasi sifat-sifat tersebut dalam pendidikan Islam adalah:

a. Sabar. Maksudnya adalah seorang muslim harus dididik dan ditanamkan sifat sabar. Terlebih bersabar dalam melakukan persiapan jhad dan bersabar tatkala berjihad. Karena kesabaran merupakan salah satu faktor yang bisa mendatangkan kemenangan. Berkaitan dengan perintah sabar dalam peperangan, Allah berfiman dalam Surat al Anfal ayat 46. 
b. Jujur. Sifat jujur harus ditanamkan dalam setiap jiwa muslim baik jujur dalam citacita, keinginan, jujur dalam perkataan dan tindakan. Dengan demikian mujahid muslim yang jujur akan amanah ketika diberikan tugas, tidak akan melakukan pengkhianatan, tidak akan membocorkan rahasia kekuatan pasukan dan tidak akan bergabung dengan musuh bagaimanapun kondisinya.

c. Semangat. Agar peperangan dalam menghadapi musuh bisa diraih oleh pasukan kaum muslimin maka salah satu kuncinya adalah adanya semangat dalam berjihad dan tidak berleha-leha atau berpangku tangan mengandalkan orang lain. Tidak mungkin peperangan akan dimenangkan sementara para mujahid tidak mau berusaha dengan sungguh-sungguh untuk meraih kemenangan tersebut. Hal ini sebagaimana yang diungkapkan oleh kata-kata bijak: Kamu berharap kesuksesan sementara kamu tidak menempuh jalan-jalannya. Sesungguhnya bahtera tidak akan bisa berlayar di daratan. ${ }^{70}$

d. Berani. Berani tampil dalam kebenaran merupakan akhlak terpuji. Seorang muslim harus memiliki sifat berani. Karena substansi jihad adalah berani dalam menanggung resiko. Karena pilihan dalam jihad adalah berani membunuh atau siap terbunuh. Dengan demikian sifat berani harus dipupuk sehingga seorang muslim berani mengorbankan waktunya, harta dan bahkan jiwanya dalam rangka di jalan Allah S.W.T.

e. Dermawan. Sifat ini harus senantiasa melekat dalam setiap jiwa muslim terlebih seorang mujahid. Dermawan merupakan bagian dari pengorbanan seorang muslim dalam aspek harta. Jihad tidak lepas dari adanya materi sehingga banyak ayat yang menyebutkan jihad hendaknya dengan harta dan jiwa. Hal ini dikarenakan dengan harta bisa didapatkan logistik, kendaraan oprasional, beragam senjata, obat-obatan, tenda-tenda dan keperluan-keperluan lainnya selama jihad berlangsung.

f. Menepati janji. Bagian dari akhlak yang terpuji adalah senantiasa menepati janji. Menepati janji merupakan bagian dari karakaterisik orang beriman sementara mengingkari janji merupakan bagian dari sifat orang munafik. Tatkala jihad diwajibkan maka kaum beriman menepati janjinya dalam menyambut seruan Allah dan Rasul-Nya, lain halnya dengan sikap kaum munafik yang tidak menepati janjinya padahal sebelumnya mereka senantiasa bertanya kapan akan melakukan jihad.

g. Penyayang. Hendaknya seorang muslim memiliki sifat penyayang, lunak dan halus terhadap sesama muslim lainnya atau bahkan kepada orang kafir selama mereka berbuat baik. Akan pentingnya sifat ini, 'Aisyah Ummul Mukiminin r.a menyebutkan sabda Nabi S.A.W: "Sifat halus tidaklah ada pada sesuatu melainkan akan menghiasinya. Dan tidaklah (sifat itu) dicabut dari sesuatu melainkan akan menjadi buruk". 71

h. Tawadhu'. Seorang muslim harus memiliki sifat tawadhu' atau rendah hati. Tawadhunya seorang mujahid akan dibuktikan dengan ketaatan baik taat kepada 
Allah, Rasul-Nya maupun kepada pimpinannya. Berkaitan dengan hakikat tawadhu', Ahmad Tafsir menyatakan bahwa tawadhu' itu salah satu indikator kepatuhan. ${ }^{72}$

i. Sifat bijak. Bijak bijak adalah mengambil keputusan dengan tepat dan tegas. Seorang muslim hendaknya memiliki sifat bijak terlebih seorang komandan perang, sehingga ia bisa mengambil setiap keputusan dengan cepat dan tepat terlebih dalam kondisi perang.

j. Menghindari akhlak tercela. Diantara akhlak tercela yang harus dihindari seorang muslim adalah tergesa-gesa, bohong, malas, kasar dan arogan, sombong, bakhil, serampangan dalam mengambil keputusan atau asal-asalan, khianat dan beberapa akhlak tercela lainnya.

\section{Aspek Spiritual}

Bagian dari program pendidikan jihad dalam kitab Jihad wa Siyar dalam aspek spiritual adalah melakukan shalat wajib, shalat sunnah, berpuasa sambil berjihad, berdoa kepada Allah, membaca al-Qur'an, mengucapkan takbir (Allahu Akbar), mengucapkan tahlil (Lâ ilâha Illallâh), dan mengucapkan tasbih (subhânallâh). Manusia sangat membutuhkan nutrisi dan asupan bagi tubuh atau jasadnya. Namun lebih jauh dari itu manusia sangat membutuhkan nutrisi dan asupan untuk ruhnya. Karena jasad tanpa ruh tentunya akan sia-sia.

Adapun implementasinya dalam pendidikan Islam dapat dilihat dalam poin-poin berikut:

a. Shalat wajib. Di tengah berkecamuknya jihad shalat wajib tetap harus didirikan, hanya saja syariat membolehkan untuk melakukan shalat dengan tatacara shalat khauf yaitu shalat dalam keadaan perang. Hal ini sebagaimana firman Allah dalam Surat an Nisa ayat 102. Shalat wajib tetap dilakukan baik dalam ketika dalam persiapan perang bahkan ketika dalam peperangan.

b. Shalat sunnah. Shalat sunnah sangat besar pengarunya dalam meneguhkan jiwa untuk selalu kokoh dan sabar dalam menghadapi ujian terlebih ujian dalam dahsyatnya jihad di jalan Allah. Jumlah musuh begitu banyak, persenjataan merekapun serba canggih ditambah lagi dengan adanya kekuatan setan dalam barisan mereka, maka tidak ada yang bisa mengalahkannya kecuali dengan mendekatkan diri kepada Allah dan memperbanyak sujud, dalam hal ini salah satunya adalah dengan shalat sunnah.

c. Berpuasa. Puasa sambil berjihad dibolehkan bagi siapa saja yang mampu melaksanakannya tanpa mengurangi kiprah dan andilnya dalam jihad di jalan Allah. Namun jika puasa tersebut justru menjadikannya lemah dalam menghadapi musuh dan maka hendaknya puasa tersebut ditinggalkan. Hal ini sebagaimana arahan Nabi S.A.W dalam mengarahkan para sahabatnya ketika akan berhadapan dengan musuh. Dalam hadits yang bersumber dari sahabat Abu Said, Rasulullah S.A.W bersabda: "Sungguh kalian di pagi hari akan berhadapan dengan musuh. Tidak berpuasa adalah jauh labih kuat bagi kalian. Oleh sebab itu berbukalah (jangan berpuasa)"73. 
d. Berdoa kepada Allah. Salah satu yang harus banyak dilakukan oleh seorang muslim yang berjuang di jalan Allah adalah memperbanyak dzikir dan berdoa kepada Allah. Doa agar diberikan kemenangan dalam menghadapi musuh merupakan hal yang dianjurkan bahkan diperintahkan dalam agama. hal ini dikarenakan doa orang yang sedang berhadapan dengan musuh termasuk doa yang akan dikabulkan. Dalam hadits yang bersumber dari sahabat Sahal bin Sa'ad r.a, bahwa Rasulullah S.A.W bersabda: "Ada dua doa yang tidak akan ditolak atau jarang sekali ditolak; berdua ketika selesai azan (antara azan dan iqamah) dan ketika berperang yaitu ketika kedua pasukan berkecamuk perang".

e. Membaca al-Qur'an. Membaca al-Qur'an dapat dilakukan dimana dan kapan saja.74 Karena ia merupakan bagian dari dzikir kepada Allah. Al-Qur'an merupakan konsumsi rohani yang tidak pernah ditinggalkan oleh orang-orang shaleh terdahulu. Hal ini sebagaimana yang dikatakan Imam Auza'i: Ada lima perkara yang senantiasa dilakukan para sahabat Nabi Muhammad dan generasi tabi'in: Senantiasa bersama dengan jamaah, mengikuti sunnah, memakmurkan masjid, membaca alQur'an dan jihad di jalan Allah. ${ }^{75}$

f. Mengucapkan takbir (Allâhu Akbar). Pada mulanya kalimat 'Allahu Akbar' biasa digunakan tatkala pasukan menaiki dataran tinggi akan tetapi hal ini dapat diimpelementasikan dengan menjadikan kalimat tersebut sebagai syi'ar atau kalimat resmi ketika menyerbu musuh, menyebrangi sungai atau jembatan dan ketika bubar dari barisan dalam setiap apel.

g. Mengucapkan tahlil (Lâ ilâha Illallâh). Mengucapkan tahlil biasanya digunakan ketika menyusuri lembah, areal jihad dan dapat juga digunakan untuk mentalqin seseorang yang akan meninggal karena terkena senjata atau peluru atau yang sedang mengalami naza' (sakaratul maut).

h. Mengucapkan tasbih (subhânallâh). Kalimat tasbih bisa diucapakan tatkala menuruni lembah, dataran yang rendah atau berjalan di daerah yang menurun.

\section{Aspek Pemahaman tentang Hakikat Jihad}

Jihad bukan dalam rangka dunia akan tetapi dalam rangka menegakan kebenaran dan meninggikan kalimat Allah serta melenyapkan kezaliman di muka bumi. Demikian juga jihad mempunyai tahapan-tahapan yaitu jihad melawan jiwa (nafsu), melawan setan, kaum yang menyimpang, munafik dan kaum kafir.

Adapun implementasinya dalam pendidikan Islam adalah:

a. Jihad melawan jiwa (nafsu) yaitu dengan belajar, mengamalkan ilmu, menyebarkan ilmu dan bersabar tatkala belajar, mengamalkan ilmu dan bersabar dalam menyebarkan ilmu.

b. Jihad melawan setan, yaitu dengan cara memperkuat keyakinan dan keimanan kepada Allah serta menambah keilmuan dengan terus belajar dengan mempelajari ilmu-ilmu yang bermanfaat. 
c. Jihad melawan penyimpangan, yaitu dengan menggunakan tangan jika mampu dalam menghentikan gerak penyimpangan tersebut, jika tidak mampu maka dengan lisan dan jika tidak mampu juga maka dengan hati.

d. Jihad melawan kaum munafik, yaitu dengan cara menghindarkan diri dari sifat munafik, meluruskan dan menjelaskan sifat dan karakteristik munafik seperti suka dusta, mengingkari janji, khianat, licik, malas shalat terlebih shalat Isya dan Subuh, jarang mengingat Allah, membenarkan faham kaum pluralis, liberal dan sekuler.

e. Jihad melawan kaum kafir, yaitu dengan cara menghindarkan diri dan lingkungan dari segala bentuk kekufuran dalam bentuk keyakinan, ucapan dan lisan, menggunakan kekuatan fisik (tangan) jika mereka yang memulai melakukan penyerangan, jika tidak mampu memerangi mereka dengan tangan maka dengan lisan, dan jika semua itu tidak mampu maka dengan hati

\section{Aspek Jasmani}

Program pendidikan jihad dalam kitab Jihad wa Siyar dalam aspek jasmani adalah menjaga kebersihan badan, melindungi dan merawat tubuh agar tidak terluka, menjaga kesehatan jasmani dengan mengobati luka, menjaga stamina dan kesehatan tubuh dengan mengkonsumsi makanan layak dan melakukan latihan sebelum berperang.

Sebagaimana sudah disebutkan, bahwa fisik yang sehat dan kuat sangat urgen. Karena seseorang yang mempunyai fisik yang sehat dan kuat akan jauh lebih tenang, fokus dan lebih produktif. Adapun implementasi dari program pendidikan jihad Imam Bukhari dalam aspek jasmani bisa dilihat dalam penjabaran berikut:

a. Menjaga kebersihan badan. Diantara bagian dari menjaga kebersihan badan adalah membersihkan debu atau tanah yang menempel di anggota badan dan pakaian, jika memungkinkan pada waktu yang luang dan sarana memungkinkan maka hendaknya melakukan mandi atau paling tidak mandi setelah berperang sebagaiman yang telah dilakukan Rasulullah S.A.W.

b. Melindungi dan merawat tubuh agar tidak terluka. Dalam rangka melindungi dan menjaga fisik agar tidak terluka, maka sebelum berangkat jihad hendaknya menggunakan peralatan yang mampu melindung fisik seperti menggunakan baju perang, tameng atau perisai, rompi kepala dan alat-alat lainnya yang mampu melindungi tubuh dari keras dan tajamnya senjata atau peluru yang bisa melukai tubuh.

c. Menjaga kesehatan jasmani dengan mengobati luka. Prinsip dalam jihad (perang) adalah membunuh atau terbunuh. Sehingga sangat mungkin seseorang akan terluka tatkala sedang terjadi jihad. Di sinilah urgensinya rumah sakit darurat didirikan dan peran tim medis diuji dalam rangka memberikan pertolongan dan pengobatan kepada kalangan yang terluka.

d. Menjaga stamina dan kesehatan tubuh dengan mengkonsumsi makanan halal dan bergizi. Jika dicermati sebagian makanan dan minuman yang dikonsumsi Nabi S.A.W seperti kurma dengan beragam namanya, daging kambing terlebih bagian pahanya, sarid, madu, susu kambing dan air putih maka akan ditemukan semuanya 
adalah makanan dan minuman yang sehat dan sarat gizi. Bahkan nyaris tidak ditemukan adanya riwayat yang menerangkan bahwa Rasulullah S.A.W sering sakit. Pola hidup sehat Rasulullah S.A.W salah satu faktornya adalah karena sering mengkonsumsi makanan halal dan bergizi.

e. Melakukan latihan sebelum berperang. Bagian dari bentuk kesiapan berjihad adalah melakukan latihan seperti latihan menungang kuda, latihan memanah, menembak dan menggunakan beragam peralatan perang lainnya. Hal ini sesuai dengan firman Allah dalam Surat al Anfal ayat 60.

\section{Aspek Kesiapan}

Yang dimaksud dengan aspek kesiapan adalah kesiapan untuk berjihad dan terangkum dalam empat hal:

a. Motivasi jihad. Di antara motivasi jihad adalah dalam rangka menegakan kalimat Allah di muka bumi dan mencari ridha-Nya, membela kehormatan agama dan kaum muslimin serta menegakan keadilan.

b. Pengadaan sarana jihad. Sarana jihad yang dibutuhkan dalam jihad selain jiwa dan harta juga sarana lain yang perlu diadakan adalah beragam bentuk senjata, menerima bantuan dari orang kafir dalam rangka melawan kaum kafir selama kendali urusan berada di tangan kaum muslimin. Akan urgensinya mengadakan saran jihad dan membantu orang yang akan berjihad, secara tersirat masuk dalam sabda Nabi S.A.W yang bersumber dari sahabat Zaid bin Khalid r.a: Barang siapa yang menyiapkan kebutuhan orang yang akan berperang maka ia telah (dianggap) berperang (jihad). ${ }^{76}$

c. Penghargaan kepada para mujahid. Penghargaan dapat berupa materi dan non materi. Diantara penghargaan dalam bentuk non materi adalah pujian dengan lisan, senantiasa memberikan apresiasi, senantiasa membela kehormatan mereka atau memberikan gelar kehormatan dan menaikan posisi atau jabatannya. Adapun diantara bentuk penghargaan dalam bentuk materi kepada para mujahid adalah dengan pemberian dan pembagian ganimah, penggalangan dana dalam rangka memenuhi kebutuhan para mujahid dan menyalurkan zakat kepada mereka serta merawat mujahid yang terluka hingga sembuh.

d. Penghargaan kepada para syuhada. Penghargaan dapat berupa materi dan non materi. Diantara bentuk penghargaan non materi adalah pujian. Penghargaan dalam bentuk pujian merupakan salah satu alat pendidikan kuratif yang mampu membangkitkan motivasi berjihad. Bagian dari bentuk penghargaan adalah menyayangi dan memperhatikan kebutuhan keluarga yang ditinggal para syuhada, menanggung keperluannya dan memberikan beasiswa bagi anak-anak para syuhada.

\section{Implementasi Metode Pendidikan Jihad Dalam Kitab Jihad Wa Siyar dalam Pendidikan Kontemporer}

Adapun implementasinya dalam pendidikan kontemporer bisa dilihat dalam penjelasan berikut: 


\section{Metode pengantar yang menarik perhatian}

Bagian dari implementasi metode ini adalah tahapan praintruksional dalam strategi pembelajaran. Seperti menanyakan kehadiran murid dan mencatat yang tidak hadir, menanyakan kepada murid sampai dimana pembahasan pelajaran sebelumnya, mengajukan pertanyaan kepada murid tentang materi yang sudah dibahas sebelumnya, mengulang pelajaran yang telah berlalu secara singkat namun mencakup semua bahan aspek yang telah dibahas sebelumnya.

Dalam mengomentari fungsi menanyakan kehadiran murid pada awal pengajaran Abdul Majid menyatakan: Tidak selalu kehadiran murid disebabkan kondisi murid yang bersangkutan (sakit, malas, bolos, dan lain-lain), tetapi bisa juga terjadi karena proses pengajaran dan guru yang tidak menyenangkan. ${ }^{77}$

\section{Metode targhib dan tarhib}

Diantara bentuk implementasinya dalam pendidikan Islam adalah guru mengungkapkan ganjaran-ganjaran alamiyah terhadap orang yang menaati perintah Allah, guru menguraikan hukuman-hukuman alamiah terhadap pelaku dosa, guru memotivasi murid untuk mendiskusikan ayat-ayat dan hadits-hadits yang mengandung targhib dan tarhib, guru menggambarkan orang-orang yang bahagia (masuk surga) karena menaati Allah, guru menggambarkan orang yang sengsara (masuk neraka) karena bermaksiat kepada Allah. ${ }^{78}$

Al Hazimi menyatakan bahwa dalam penggunaan metode ini guru dituntut untuk berlaku adil dan tidak timpang dalam menggunakan kedua metode tersebut serta diterapkan sesuai dengan kondisi yang tepat. ${ }^{79}$

\section{Metode amtsal (perumpamaan)}

Metode ini dapat digunakan guru dalam mengajar muridnya. Pengungkapannya tentu saja sama dengan metode lain seperti metode kisah, yaitu dengan berceramah atau membaca teks. Diantara kelebihan metode ini adalah mempermudah murid memahami konsep yang abstrak, dapat merangsang kesan terhadap makna yang tersirat dalam perumpamaan tersebut, merupakan pendidikan agar bila menggunakan perumpamaan haruslah logis dan mudah dipahami dan metode ini bisa memberikan motivasi kepada pendengarnya untuk berbuat amal baik dan menjauhi kejahatan. ${ }^{80}$

\section{Metode reward dan funishment}

Guru harus menguasai metode ini dan menerapkannya secara adil. ${ }^{81}$ Dalam dunia pendidikan, reward digunakan sebagai bentuk motivasi atau sebuah penghargaan untuk hasil atau prestasi yang baik, dapat berupa kata-kata pujian, pandangan senyuman, pemberian tepukan tangan serta sesuatu yang menyenangkan anak didik, misalnya pemberian beasiswa bagi yang telah mendapat nilai bagus. Sementara funishment dapat berupa ancaman, larangan, pengabaian dan pengisolasian, hukuman badan sebagai bentuk hukuman yang diberikan pada seseorang karena kesalahan, pelanggaran hukum dan peraturan dalam perbaikan dan pembinaan umat manusia. Dalam Islam, apabila seseorang mendapat hukuman, termasuk ta'zir, maka hukuman berkisar antara peringatan, kecaman, pukulan, kurungan dan rampasan (Miller, 2002:170). 
Adapun al Hazimi menyebutkan beberapa bentuk dari funishment bisa dengan menampakan ketidak sukaan, kecaman, larangan, mengisolir dan pukulan. ${ }^{82}$

\section{Metode wirid}

Ahmad Tafsir menyatakan bahwa biasanya wirid dilakukan tatkala selesai melaksankan shalat. Di pesantren pada umumnya, setiap selesai magrib kebanyakan tetap tinggal di masjid. Mereka tidak pulang ke rumah. Mereka wiridan sambil menunggu shalat isya. Tidak jarang para santri pun ikut wiridan.

Wiridan juga sering dilakukan tatkala selesai shalat subuh dan dilakukan hingga menjelang terbitnya matahari. ${ }^{83}$

\section{Metode hiwar}

Hiwar (dialog) ialah percakapan silih berganti antara dua pihak atau lebih mengenai suatu topik dengan diarahkan oleh guru kepada satu tujuan yang dikehendaki. Dalam dialog itu bahan pembicaraan tidak dibatasi; dapat digunakan berbagai konsep sain, filsafat, seni, wahyu dan lain-lain. ${ }^{84}$ Dengan demikian, metode ini bisa digunakan dalam seluruh bidang studi.

\section{Metode kasih sayang}

Metode ini melahirkan rasa cinta dan kasih sayang. Melalui penumbuhan rasa cinta dan kasih sayang ini, dapat menumbuhkan semangat murid untuk belajar. Dari penumbuhan rasa ini pula anak mampu mengaplikasikan materi pembelajaran yang diterimanya sebab murid telah menerima dan mengolah materi dengan baik dan senang hati tanpa adanya perasaan tertekan atau terpaksa oleh tuntutan kewajiban sebagai seorang murid.

Dengan metode ini proses kegiatan belajar mengajar (KBM) akan menjadi lebih menyenangkan. Karena guru akan berusaha mengenali dan memahami dunia murid. Tidak berhenti di situ saja, guru perlu memahami apa yang sedang dirasakan oleh murid-muridnya. Dari situ guru dapat mengkaji lagi mengenai bagaimana keadaan murid dan cara terbaik untuk membantu mengatasi masalah dan membimbingnya. ${ }^{85}$

\section{Metode tanya jawab}

Diantara penerapan metode ini dalam pendidikan adalah adanya dialog antara guru dan murid. Misalnya guru mengajukan pertanyaan kepada murid, kemudian murid menjawab pertanyaan tersebut. Metode ini mampu merangsang berpikir murid dan membimbingnya dalam mencapai atau mendapatkan pengetahuan.

Dalam komunikasi ini terlihat adanya hubungan timbal balik secara langsung antara guru dan murid. 86

\section{Metode ceramah}

Metode ceramah merupakan metode yang sampai saat ini sering digunakan oleh setiap guru dan instruktur. Hal ini selain disebabkan oleh beberapa pertimbangan tertentu, juga adanya faktor kebiasaan baik dari guru ataupun murid. Metode ceramah biasanya digunakan jika ingin mengajarkan topik atau materi baru, tidak ada sumber pelajaran pada murid, atau menghadapi jumlah murid yang cukup banyak. ${ }^{87}$ 


\section{Metode murasalah (korespondensi)}

Ali Zahrani menyatakan metode ini merupakan metode klasik namun masih dipakai hingga saat ini. Bahkan saat ini ada lembaga-lembaga pendidikan yang menggunakan metode korespondensi dalam proses pembelajarannya seperti sebagian universitas yang menggunakan metode intisab (jarak jauh) dalam proses perkuliahanannya. Sehingga bahan-bahan perkuliahan demikian juga dengan penyelsaian tugas-tugas diseselsaikan dengan pola jarak jauh. Masih menurutnya, implementasinya dalam pendidikan adalah kadang guru menggunakan metode ini. Termasuk karya tulis ilmiah dan hasil riset masih menggunakan metode korespondensi. ${ }^{88}$

\section{Metode tulisan}

Tulisan merupakan salah satu sarana yang bisa menjaga dan memelihara keberlangsungan ilmu, gagasan dan karya seseorang. Metode ini di pesantren diterapkan dalam pelajaran imla' (dikte). Demikian juga bisa diterapkan tatkala murid menyimak penjelasan guru dan mencatat poin-poin penting yang disampaikan guru. ${ }^{89}$

\section{Metode kisah}

Kisah dalam pendidikan islami, terutama pendidikan agama Islam (sebagai suatu bidang studi), kisah sebagai metode pendidikan amat penting. Kisah tersebut baik yang bersumber dari al-Qur'an maupun dari hadits Nabi S.A.W.90

Al Hazimi menyatakan adapun kisah yang diada-adakan atau yang tidak jelas sumbernya, maka hal itu termasuk dalam katagori kisah dusta yang tidak layak diceritakan dan digunakan dalam pendidikan. ${ }^{91}$ Sumber kisah yang bisa dijadikan referensi selain al-Qur'an dan hadits menurut al Hazimi adalah buku-buku sejarah yang valid, biografi tokoh, dan kejadian-kejadian ril yang terjadi di masyarakat. ${ }^{92}$

\section{Metode tugas}

Metode tugas termasuk bagian dari metode pendidikan. Tugas bisa dalam bentuk penghafalan, pembacaan, pengulangan, pengujian dan pemeriksaan atas diri sendiri, atau menampilkan diri dalam menyampaikan suatu (puisi, syair, drama) atau melakukan kajian maupun uji coba sesuai dengan tuntutan kualifikasi atau kompetensi yang ingin dicapai. Tugas sendiri bisa dilaksanakan di sekolah, perpustakaan dan tempat lainnya. ${ }^{93}$

\section{Metode peneladanan (qudwah)}

Metode peneladanan sangat penting dalam dunia pendidikan, karena sangat efektif dalam mempengaruhi dan merubah prilaku seseorang. Implementasi metode ini dalam pendidikan adalah murid cenderung meneladani gurunya. Hal ini diakui oleh semua ahli pendidikan, baik dari Barat maupun dari Timur. Dasarnya adalah karena secara psikologis anak memang senang meniru; tidak saja yang baik, yang jelek pun ditirunya. ${ }^{94}$

Dalam pernyataan lainnya, Ahmad tafsir menyatakan bahwa metode meniru atau meneledanai merupakan bagian dari metode internalisasi yang sangat efektif. Karena 
murid secara psikologis senang meniru, kedua karena sanksi-sanksi sosial, yaitu seseorang akan merasa bersalah bila ia tidak meniru orang-orang di sekitarnya. ${ }^{95}$

Dengan demikian pendidikan islami berpusat pada keteladanan. Dan yang menjadi teladan bisa jadi guru, kepala sekolah dan semua aparat sekolah. Sementara teladan untuk para guru tersebut adalah Rasulullah S.A.W. ${ }^{96}$

\section{Metode kerja kelompok}

Metode ini mengandung pengertian bahwa murid dalam satu kelas dipandang sebagai satu kesatuan (kelompok) tersendiri ataupun dibagi atas kelompok-kelompok kecil (sub-sub kelompok). Pembentukan kelompok ini bisa berdasarkan perbedaan individual dalam kemampuan belajar, perbedaan minat belajar, jenis pekerjaan dan bisa juga atas dasar perbedaan wilayah. ${ }^{97}$

\section{Metode pengulangan}

Dalam dunia pendidikan metode ini termasuk metode klasik dan tradisional atau bahkan tergolong super konvensional. Meskipun demikian metode ini sangat penting. Metode pengulangan bisa dilakukan guru ketika menjelaskan sesuatu yang penting untuk diingat murid. Atau digunakan tatkala mendapatkan adanya murid yang belum memahami materi pelajaran sehingga perlu adanya pengulangan.

\section{Metode pendelegasian}

Pada sebagian sekolah metode pendelegasian digunakan pada momen-momen tertentu. Seperti mendelegasikan muridnya untuk menghadiri seminar dalam tema tertentu. Hal ini dilakukan salah satunya dalam rangka menambah dan memperkaya wawasan murid. Seperti yang dilakukan Sekolah Menengah Kejuruan (SMK) al Irsyad kota Tegal yang mendelegasikan pengurus OSIS-nya untuk menghadiri dan mengikuti seminar dengan tema Mewaspadai Bahaya Syiah dan Komunis. ${ }^{98}$

\section{Metode mengeraskan suara ketika mengajar}

Metode mengeraskan suara ketika mengajar merupakan bagian dari metode penting dalam pendidikan kontemporer. Terlebih tatkala jumlah murid sangat banyak, tempat yang luas sementara perangkat sound system berjalan tidak maksimal. Selain karena faktor tadi, Ali Zahrani menjelaskan bahwa metode ini juga sangat tepat diterapkan dalam rangka menyampaikan materi yang sangat penting diketahui murid, dalam rangka meluruskan kesalahan yang tidak boleh dibiarkan dan ditidak boleh diakhirkan penjelasannya. ${ }^{99}$

\section{Metode isyarat}

Metode isyarat adalah metode non verbal. Yaitu gerakan anggota tubuh seperti menggunakan isyarat dengan tangan atau kepala. Dalam pengajaran metode ini senantiasa melekat pada diri seorang guru dalam proses pembelajaran. Implementasinya dalam pendidikan adalah berfungsi untuk menarik perhatian murid ${ }^{100}$ dan metode ini juga bisa diterapkan dalam proses pembelajaran kaum tuna rungu.

\section{Metode mau'idzah}


Mau'idzah artinya nasehat dan peringatan dengan menyebutkan ancaman. Maksudnya adalah memberi peringatan kepada manusia dengan pahala dan ancaman sehingga hatinya menjadi luluh (tersentuh).101

Sementara Ahamd Tafsir menyatakan bahwa mau'idzah artinya nasehat yang lembut yang diterima oleh hati dengan menjelaskan pahala atau ancaman.102 Implemenasinya dalam pendidikan adalah penyampaian nasehat harus dilakukan secara serius, prihatin, ikhlas dan berulang-ulang. ${ }^{103}$

\section{Implementasi Evaluasi Pendidikan Jihad dalam Kitab Jihad Wa Siyar dalam Pendidikan Kontemporer}

Sebagaimana yang sudah dijelaskan dalam bab sebelumnya bahwa evaluasi pendidikan jihad dalam kitab Jihad wa Siyar terdiri dari beberapa item diantaranya melakukan evaluasi dengan memperhitungkan jumlah dan kekuatan pasukan, melakukan evaluasi dengan memberikan sanksi, mengevaluasi dengan merubah sanksi, mengevaluasi penyebab kekalahan, mengevaluasi kondisi keamanan, melakukan evaluasi dengan menyiapkan komandan cadangan dan mengevaluasi keikutsertaan dalam jihad.

Adapun implementasinya dalam evaluasi pendidikan kontemporer adalah sebagai berikut:

1. Melakukan evaluasi dengan memperhitungkan jumlah murid

2. Melakukan evaluasi dengan memberikan sanksi

3. Melakukan evaluasi dengan merubah sanksi

4. Mengevaluasi penyebab nilai rendah

5. Mengevaluasi kondisi keamanan sekolah

6. Melakukan evaluasi dengan menyiapkan guru cadangan (guru piket)

7. Mengevaluasi kehadiran murid

Berikut ini adalah penjelasan secara global dari implementasi evaluasi pendidikan jihad Imam Bukhari dalam pendidikan kontemporer:

\section{Melakukan evaluasi dengan memperhitungkan jumlah murid}

Maju mundurnya sekolah bisa terlihat dari beberapa indikasi. Diantaranya dengan melihat jumlah murid. Jika jumlah murid naik dan banyak murid yang minat belajar di sekolah tersebut, maka ini merupakan indikasi sekolah tersebut bagus dan berkualitas. Akan tetapi jika jumlah murid berkurang dan terus cenderung menurun, maka ini merupakan indikasi jika sekolah tersebut tidak berkualitas.

Jumlah murid yang sedikit sangat berpengaruh dalam proses pembelajaran. Bahkan Dinas Pendidikan kota Semarang akan menggabung atau regrouping sekolah yang kekurangan peserta didik. Bunyamin sebagai kepala Dinas menyatakan, "Kami masih melakukan evaluasi terhadap sekolah yang jumlah muridnya turun dari tahun ke tahun".104

\section{Melakukan evaluasi dengan memberikan sanksi}


Ketika tersiar kabar akan adanya acara pesta bikini yang dilakukan anak-anak Sekolah Menengah Atas (SMA) dengan tema "Splash After Class" dan akan diselenggarakan pada 25 April 2015 di The Media Hotel \& Towers di Jalan Gunung Sahari Raya Nomor 3. Menurut klaim panitia penyelenggara, ada beberapa sekolah yang mendukung acara tersebut diantaranya SMA 8 Bekasi, SMA 12 Jakarta, SMA 14 Jakarta, SMA 38 Jakarta, SMA 50 Jakarta, SMA 24 Jakarta, SMK Musik BSD, SMA 109 Jakarta, SMA 53 Jakarta, SMA Muhammadiyah Rawamangun, SMA 44 Jakarta, SMA Alkamal, SMA 29 Jakarta, SMA 26 Jakarta, dan SMA 31 Jakarta. 105

Maka gubernur DKI meminta kepada dinas terkait untuk memberikan sanksi kepada murid yang mengikuti pesta bikini selepas Ujian Nasional. Tindakan tergas dengan memberikan sanksi merupakan bagian dari bentuk evaluasi atas sikap murid yang melanggar norma-norma yang telah ditetapkan pihak sekolah.

\section{Melakukan evaluasi dengan merubah sanksi}

Jika diimplementasikan dalam dunia perguruan tinggi, maka dalam mengevaluasi hasil belajar mahamurid dilakukan sekurang-kurangnya tiga kali, yaitu Ujian Tengah Semester (UTS), dan Ujian Akhir Semester (UAS), serta evaluasi lainnya yang tidak bertentangan dengan peraturan yang berlaku. ${ }^{106}$ Dengan demikian mahamurid yang belum memenuhi evaluasi akhir semester akan diberi nilai dengan huruf T (Komponen Penilaian Tidak Lengkap).

Setelah evaluasi pada butir (1) dipenuhi mahamurid dalam waktu 2 minggu terhitung sejak ujian akhir semester mata kuliah bersangkutan huruf $\mathrm{T}$ harus diganti menjadi nilai A, B, C, D, atau E. Apabila evaluasi pada butir (1) tidak dipenuhi dalam batas waktu 2 minggu, maka huruf mutunya menjadi E; atau Dosen Pengasuh mata kuliah dapat mengolah sesuai dengan bobot masing-masing bagian evaluasi yang ditetapkan, sehingga menghasilkan huruf mutu lain. Huruf T tidak dapat diubah menjadi Huruf $\mathrm{K}$, kecuali apabila mahamurid tidak dapat menempuh ujian akhir semester susulan atas dasar alasan yang dapat dibenarkan (sakit, mengalami kecelakaan, atau musibah yang memerlukan perawatan lama). ${ }^{107}$

\section{Melakukan evaluasi atas rendahnya nilai dan jumlah kelulusan}

Seorang guru harus mengevaluasi faktor yang menjadikan nilai muridnya rendah atau faktor yang menjadikan murid rendah dalam nilai ujian kelulusan. Banyak faktor yang menjadikan nilai murid rendah. Bisa jadi karena faktor murid, atau karena faktor guru dan juga bisa karena faktor sarana prasarana sekolah yang kurang memadai.

Ketika ada beberapa murid sekolah yang tidak lulus dalam Ujian Nasioanl (UN) di jajaran Dinas Pendidikan Sukoharjo, maka kepala Disdiknya menyatakan akan terus melakukan evaluasi hingga di tahun berikutnya diharapkan terus menurun hingga nol dan menaikan tingkat kelulusan menjadi $100 \%{ }^{\prime 108}$

\section{Mengevaluasi kondisi keamanan sekolah}

Kondisi keamanan sekolah sangat mempengaruhi kualitas proses pendidikan dan prestasi murid. Ketika kondisi sekolah tidak aman seperti meningkatnya kasus kriminal di kalangan murid, pelecehan antar murid, perbuatan mesum, absensi, bunuh diri dan 
putus sekolah maka sangat mempengaruhi proses belajar mengajar. Jika hal ini terjadi maka pihak lembaga pendidikan hendaknya melakukan evaluasi diantaranya mengevaluasi kinerja para guru dan karyawannya.

Evaluasi guru diperlukan sebagai parameter untuk mengukur pencapaian prestasi kerja guru, sekaligus sebagai titik tolak pengembangan program pendidikan guru selanjutnya (Wan Mo et.al., 1998). Evaluasi guru juga merupakan bagian dari siklus keprofesionalan seseorang ketika dia memutuskan untuk menerjuni profesi guru (Nevo, 1994). ${ }^{109}$

\section{Melakukan evaluasi dengan menyiapkan guru piket}

Dengan pertimbangan adanya guru yang berhalangan mengajar sehingga implikasinya akan membuat kelas gaduh dan tidak kondusif, maka sebagian lembaga pendidikan mengambil langkah antisipasi dengan membentuk guru piket. Dan diantara tugasnya adalah menggantikan guru yang berhalangan. Disebagian pesantren dikenal dengan istilah asisten ustadz. Ketika ustadz pengampu materi tertentu berhalangan maka asisten tersebut yang menggantikannya dalam mengajar.

\section{Mengevaluasi kehadiran murid}

Mengevaluasi kehadiran murid diantaranya dengan membuat absensi. Absensi adalah sebuah kegiatan pengambilan data guna mengetahui jumlah kehadiran murid. Setiap kegiatan yang membutuhkan informasi mengenai peserta tentu akan melakukan absensi. Hal ini juga terjadi pada proses belajar. Kegunaan absensi ini terjadi pada pihak murid dan pihak penyelenggara proses belajar mengajar dalam hal ini adalah guru. Salah satu kegunaan absensi ini bagi pihak murid adalah dalam rangka mengetahui mungkin tdaknya bisa mengikuti ujian. Dan salah satu kegunaan informasi absensi ini bagi guru antara lain untuk melakukan evaluasi tentang kepuasan murid atas suatu mata pelajaran dan membuat perencanaan yang matang dan lebih baik dalam memberikan pelajaran kepada para murid.

\section{Kesimpulan}

Dari kajian dan pembahasan tentang pendidikan jihad dalam kitab Jihad wa Siyar Shahih Bukhari dan implementasinya dalam pendidikan Islam dengan menjadikan seluruh bab dab hadits yang ada dalam kitab Jihad wa Siyar sebagai objek penelitian, maka dapat ditarik beberapa kesimpulan sebagai berikut:

1. Tujuan pendidikan jihad dalam kitab Jihad wa Siyar adalah menjadikan seorang muslim memiliki keimanan dan keikhlasan sebagai landasan amal, memiliki akhlak yang mulia, memiliki spiritualitas yang baik, memiliki pemahaman tentang hakikat jihad, memiliki fisik yang sehat dan kuat serta memiliki kesiapan untuk berjihad. Adapun implementasinya dalam pendidikan Islam adalah lulusan harus memiliki iman yang kuat, lulusan harus memiliki akhlak yang mulia, lulusan harus memiliki spiritualitas yang baik, lulusan harus memiliki ilmu dan wawasan yang luas, lulusan harus memiliki fisik yang sehat dan kuat serta harus memiliki kesiapan untuk berjihad. 
2. Program pendidikan jihad dalam kitab Jihad wa Siyar mencakup enam aspek yaitu:

a. Aspek keimanan, yaitu hal-hal yang terkait iman kepada Allah seperti ikhlas, cinta, ta'at dan tawakal. Adapun implementasinya dalam pendidikan adalah ikhlas dalam berjihad, cinta kepada Allah, Rasulullah dan kaum muslimin, ta'at kepada Allah, Rasul-Nya dan pimpinan, berharap mendapatkan pahala dari Allah, dan tawakal kepada Allah setelah melakukan usaha secara maksimal.

b. Aspek akhlak, yaitu yang terkait akhlak seperti sabar, jujur, antusias, berani, dermawan, menepati janji, penyayang, tawadhu', bijak dan menghindari sifatsifat tercela. Adapun implementasinya dalam pendidikan adalah sabar ketika melakukan persiapan jihad dan tatkala terjadi jihad, jujur dalam cita-cita dan keinginan serta jujur dalam perkataan dan tindakan, semangat dalam, berani mengambil resiko dalam jihad, dermawan dengan menginfakan hartanya di jalan Allah, menepati janji dengan menyambut seruan jihad, sayang kepada sesama mujahid dan keluargnya, tawadhu dengan patuh atas perintah pimpinan selama dalam kebaikan, bijak dalam mengambil keputusan terlebih pada saat-saat genting dan menghindari akhlak tercela seperti tergesa-gesa, bohong, malas, kasar dan arogan, sombong, bakhil serta akhlak tercela lainnya.

c. Aspek spiritual yang mencakup mendirikan shalat wajib, shalat sunnah, puasa sambil berjihad, berdoa kepada Allah, membaca al-Qur'an, mengucapkan takbir (Allahu Akbar), mengucapkan tahlil (Lâ ilâha Illallâh), dan mengucapkan tasbih (subhânallâh). Adapun implementasinya dalam pendidikan Islam adalah shalat wajib di sela-sela jihad, shalat sunnah setelah pulang dari jihad, berpuasa wajib dan sunnah bagi yang mempunyai kemampuan, banyak berdoa tatkala berhadapan dengan musuh, membaca al-Qur'an dan menjadikannya sebagai penenang hati dalam berjihad, mengucapkan takbir ketika mendaki, menyerbu, menyebrangi sungai dan jembatan serta bubar dalam baris berbaris, mengucapkan tasbih ketika menuruni dataran rendah seperti menuruni perbukitan dan lembah, serta mengucapkan tahlil ketika menyusuri jalanan atau areal jihad.

d. Pemahaman hakikat jihad, yaitu yang terkait dengan jihad melawan jiwa (nafsu), jihad melawan setan, jihad melawan penyimpangan, jihad melawan kaum munafik dan jihad melawan kaum kafir. Adapun implementasinya dalam pendidikan adalah seorang muslim mampu mengendalikan jiwanya (nafsunya) dengan cara belajar, mengamalkan ilmunya, mengajarkan ilmu, dan bersabar dalam belajar, mengamalkan ilmu dan sabar dalam mengajarkan ilmu; melawan godaan setan dengan memperkuat keyakinannya kepada Allah dan memperkaya dengan ilmu yang benar; mencegah pemahaman yang menyimpang dan kemungkaran dengan kekuatan tangan, lisan dan hati; menghindari beragam sifat kemunafikan dan menjelaskan karakteristik kaum munafik; menghindari beragam bentuk kekufuran dan melawan kaum kafir dengan kekuatan tatkala mereka lebih dulu melakukan penyerangan. 
e. Aspek jasmani, yaitu yang terkait dengan menjaga kebersihan badan, melindungi dan merawat tubuh agar tidak terluka, menjaga kesehatan jasmani dengan mengobati luka, membawa perbekalan dalam rangka menjaga stamina dan kesehatan tubuh dan melakukan latihan sebelum berperang. Adapun implementasinya dalam pendidikan Islam adalah seorang muslim membersihkan debu atau kotoran yang menempel di badan atau pakaiannya dan mandi setelah berjihad; melindungi dan merawat tubuh agar tidak terluka dengan menggunakan baju besi, rompi kepala dan tameng atau perisai; menjaga kesehatan fisik dengan mengobati luka yaitu tidak membiarkan luka tersebut dan harus secepatnya diberikan terapi, menjaga stamina dan kesehatan tubuh dengan mengkonsumsi makanan yang halal dan bergizi; dan melakukan latihan sebelum berperang seperti latihan berkuda, memanah, beladiri dan latihan menembak.

f. Aspek kesiapan berjihad, yaitu yang berkaitan dengan motivasi jihad, sarana jihad, penghargaan kepada para mujahid, dan dan penghargaan kepada syuhada. Adapun implementasinya dalam pendidikan adalah motivasi jihad dalam rangka meraih ridha Allah, menolong kaum muslimin dan menjaga agama; sarana jihad adalah jiwa dan harta serta memanfaatkan kekuatan kaum kafir dalam memerangi kaum kafir lagi serta melenyapkan sarana jihad yang bisa dimanfaatkan kaum kafir tatkala para mujahid terdesak; memberikan penghargaan kepada mujahid baik secara materi seperti memberi ganimah, penggalangan dana dan menyalurkan zakat kepada mereka dan non materi seperti pujian, pembelaan, dan gelar yang baik; memberikan penghargaan kepada syuhada dan keluarganya baik secara materi seperti memenuhi kebutuhan kelaurga yang ditinggal, memberikan beasiswa pendidikan bagi anakanaknya dan penghargaan non materi seperti memuji dan mendoakannya.

3. Metode pendidikan jihad Imam Bukhari

Paling tidak ada 20 metode pendidikan yang ditemukan dalam metode pendidikan jihad Imam Bukhari, diantaranya metode pengantar yang menarik perhatian, metode targhib dan tarhib, metode amtsal (perumpamaan), metode reward dan funsihment, metode wirid, metode hiwar, metode kasih sayang, metode tanya jawab, metode ceramah, metode murasalah (korespondensi), metode tulisan, metode kisah, metode tugas, metode peneladanan (qudwah), metode kerja kelompok, metode pengulangan, metode pendelegasian, metode mengeraskan suara ketika mengajar, metode isyarat dan metode mau'idzah. Seluruh metode pendidikan tersebut dapat diimplementasikan dalam metode pendidikan Islam.

\section{Evaluasi pendidikan jihad Imam Bukhari}

Diantara poin-poin penting berkaitan evaluasi pendidikan jihad Imam Bukhari adalah melakukan evaluasi dengan memperhitungkan jumlah dan kekuatan pasukan, mengevaluasi kondisi kemanan, melakukan evaluasi dengan menyiapkan para komandan cadangan, mengevaluasi penyebab kekalahan, melakukan evaluasi dengan memberikan sanksi, melakukan evaluasi dengan merubah sanksi dan mengevaluasi 
keikutsertaan dalam jihad. Adapun implementasinya dalam evaluasi pendidikan kontemporer adalah melakukan evaluasi dengan memperhitungkan jumlah murid, mengevaluasi kondisi keamanan sekolah, melakukan evaluasi dengan menyiapkan guru cadangan (guru piket), mengevaluasi penyebab nilai rendah, melakukan evaluasi dengan memberikan sanksi, melakukan evaluasi dengan merubah sanksi dan mengevaluasi kehadiran murid.

\section{REFERENCES}

1 Abû Bakar Jâbir al Jazâirî, Minhâj al Muslim, Beirut: Dâr al Fikr, 1992, hlm. 4.

2 Demikian kalimat yang sering diungkapan Ahmad Tafsir dan bisa dilihat dalam beberapa buku beliau diantaranya buku Ilmu Pendidikan Islami.

3 Mantan Guru Besar Ilmu Pendidikan Islam UIN Sunan Gunung Djati Bandung

4 Ahmad Tafsir, Filsafat Pendidiikan Islami, Bandung: PT. Rosda, 2010, hlm. 100.

5 Ahmad Tafsir, Filsafat Pendidiikan Islami, hlm. 28. Lihat juga dalam bukunya yang lain Ilmu Pendidikan Islami, Bandung: Rosda, 2012, hlm. 107.

6 Ahmad Tafsir, Filsafat Pendidikan Islami, 79-80.

7 Guru Besar Ilmu Pendidikan Islam UIN Syarif Hidayatullah Jakarta

8 Abuddin Nata, Kapita Selekta Pendidikan Islam; Isu-Isu Kontemporer tentang Pendidikan Islam; Depok: PT. Rajawali Pers, 2013, hlm. 110.

9Abul Hasan 'Ali an Nadawî, Nahwa at Tarbiyah al Islâmiyah al Hurrah, Fil Hukûmât wal Bilâd al Islâmiyah, Beirut: Dârul Irsyâd, 1969, hlm. 21-23.

10 Abû Bakar Jâbir al Jazâirî, Minhâj al Muslim, hlm. 347.

11 Muhyiddin Arubusman, et.al., Terorisme Di Tengah Arus Global Demokrasi, Bekasi: Spectrum, 2006, hlm. 236.

12 LihatAhmad Mansur Surya Negara, Api Sejarah, Bandung: Salmadani, 2013, Cetakan keenam, hlm. 258-266

13 Ibn Katsir, Tafsir al-Quran al 'Adzim, Riyad: Dar Thayyibah, 1999, Vol. 8, hlm. 27-28

14 Ahmad, Musnad Imam Ahmad, vol. 9, hlm. 124, hadits no. 5114. Atau lihat Ibn Katsir, Tafsir al-Quran al 'Adzim, Vol. 8, hlm. 28

15 Negara yang mempunyai kekuasaan lebih di percaturan politik internasional baik dalam mempengaruhi peristiwa-peristiwa global maupun lebih jauh mengambil keputusan dalam proyek-proyek internasional. Negara seperti ini biasanya dianggap sebagai pemimpin oleh negara-negara lainnya.

16 Mahmud Syits Khaththab, al 'Askariyah al Israiliyah, Beirut: Dar atThaliah, 1968, hlm. 117

17 Untuk lebih rincinya lihat Abdullâh bin Furaih al 'Aqlâ, I'dâd al Jundî al Muslim Ahdâfuh wa Ususuh, Riyad: Maktabah ar Rusyd, 2003, hlm. 55.

18 Sayyid Abdul Ghanî, Haqîqah al Walâ wal Barấ' Fî Mu'taqad Ahli as Sunnah wal Jamâ'ah, Beirut: Dâr Ibn Hazm, 1998, hlm. 616.

19 Ibrahîm bin Mûsâ as Syâtibî, al Muwâfaqât, tahqîq Masyahûr Âlû Salmân, Cairo: Dâr Ibn 'Affân, 1997, vol. II, hlm. 64.

20 Ibn Abi al 'Izz, Syarh Aqîdah at Thahâwiyah, Beirut: al Maktab al Islamî, 1988, hlm. 387.

21 Abdullâh bin Furaih al 'Aqlâ, I'dâd al Jundî al Muslim Ahdâfuh wa Ususuh, Riyad: Maktabah ar Rusyd, 2003, hlm. 45.

22 Ahmad Ibn Taimiyah al Hârrânî, Majmu' al Fatâwâ, vol. X, hlm. 152

23 Ahmad Ibn Taimiyah al Hârrânî, Al 'Ubudiyah, Beirut: al Maktab al Islâmî, 2005, hlm. 94 dan dalam karyanya yang lain yaitu Al Fatâwâ al Kubrâ, Beirut: Dâr al Kutub al Ilmiyah, 1987, vol. V, hlm. 188.

24 Muhyiddin Arubusman, et al., Terorisme Di Tengah Arus Global Demokrasi, hlm. 236

25Khâlid Ahmad al Syantût, Al Muslimûn wat Tarbiyah al 'Askariyah, pengantar 'Ali Juraisyah, Madinah Munawwarah: Tanpa penerbit, 1989, hlm. 63. 
26 Abul A'lâ al Maudûdî, et al., Jihad Fi Sabilillah, Jakarta: Media Dakwah, 1986, hlm. ix 27 Abul A'lâ al Maudûdî, et al., Jihâd Fî Sabîlillâh, hlm. ix.

28 www.eramuslim.com, Sabtu, 17 Syawwal 1434 H /24 Agustus 2013 16:19 WIB. Diakses pada tanggal 30 Oktober 2013, jam 06.21.

29 http://hmmmesir.20m.com/001jihadasnan.htm. Diakses pada tanggal 30, oktober 2013.

30 'Abdullâh Azzâm, Tarbiyah al Jihâd wal Binâ, Pesyawar: Markaz as Syahîd 'Azzâm al I'lâmî, 1413 H, hlm. 5.

31 'Ali Syâhîn, al I'lâm Binaqdhi Mâ Jâ'a Fî Kitâb Maqâlah Fil Islâm, Cairo: Dârut Thabâ'ah al Muhammadiyah, 1998, hlm. 102-103.,

32 'Ali Syâhîn, al I'lâm Binaqdhi Mâ Jâ'a Fî Kitâb Maqâlah Fil Islâm, hlm 103. Lihat juga Khâlid Ahmad al Syantût, Al Muslimûn wat Tarbiyah al 'Askariyah, hlm. 63.

33 Muhammad Muhammad Husain, al Ittijâhât al Wathaniyah Fi al Adab al Mu'âshir, Alexanderia: Maktabah al Adab, vol. II, hlm. 32.

34 Diterbitkan oleh Cambridge University Press 2 nd ed. 1965.

35 Ahmad Ghurâb, Ru'yah Islâmiyah Li al Istisyrâq, London: Al Muntadâ al Islâmî, 1411 H, hlm. 98.

36 Khâlid Ahmad as Syantût, Al Muslimûn wat Tarbiyah al 'Askariyah, diberi pengantar oleh 'Ali Juraisyah, Madinah Munawwarah: Tanpa penerbit, 1989, hlm. 1-2.

37 Mantan Ketua Umum PP Muhammadiyah

38http://www.pelita.or.id/baca.php?id=68347, diakses pada tanggal 30 oktober 2013, jam 10.22 .

39http://www.voa-islam.com/news/opini/2013/09/26/26971/amien-rais-janganmenjadikan-orang-kafir-sebagai-pemimpin/. Diakses pada tanggal 30 Oktober 2013, jam 10.21.

40 Khâlid Ahmad as Syantût, Al Muslimûn Wat Tarbiyah al 'Askariyah, hlm. 23.

41 Khâlid Ahmad as Syantût, Al Muslimûn Wat Tarbiyah al 'Askariyah, hlm. 35

42 Khâlid Ahmad as Syantût, Al Muslimûn Wat Tarbiyah al 'Askariyah, hlm. 11. Lihat juga Sayyid Quthb, Tafsîr Fî Dzilâl al Qur'ân, vol. III, hlm. 432.

43Khâlid Ahmad as Syantût, Al Muslimûn Wat Tarbiyah al 'Askariyah, hlm. 11.

44 Abdullâh Nâshih Ulwân, Tarbiyatul Aulâd Fil Islâm, Cairo: Dârus Salâm, 1992, cetakan kedua, hlm. 925 dan 995-1000.

45 Khâlid al Hâzimî, Ushûl at Tarbiyah al Islâmiyah, Madinah Munawwarah: Dâr 'Âlamil Kutub, 2000, hlm. 191-213., Lihat juga Fauziyah Ridhâ Amîn Khayyâth, Al Ahdâfat Tarabawiyah as Sulûkiyah 'Inda Syakihil Islâm Ibn Taimiyah, Mekah: Maktabah al Manârah, 1987, hlm. 170171.

46Nama kitabnya adalah Al Jâmi' al Musnad as Shahîh al Mukhtashar Min Umûr Rasûlillâh S.A.W wa Sunanih wâ Ayyâmih.

47Jalâluddîn al Suyûthî, Tadrîb ar Râwî fí Syarh Taqrîb an Nawawî, Beirut: Dârul Fikr, 1993, hlm. 50-51.

48 Beliau dulunya adalah salah seorang guru besar hadits di Universitas Al Azhar Cairo Mesir

49 Muhammad Abû Zahwu, al Hadîts wal Muhadditsûn, Cairo: Maktabah Taufîqiyah, 1959, hlm. 379.

50 Lihat http://www.kompasiana.com/nararyanggadas/istilah-library-research-dalam-karyatulis-ilmiah-tepat 54f74265a33311b2708b4829. Dikutip pada hari Selasa, 21 Juli 2015.

51 Wina Sanjaya, Penelitian Pendidikan: Jenis, Metode dan Prosedur, Jakarta: Kencana, 2014, hlm. 205

52 http://lib.uin-malang.ac.id/files/thesis/chapter iii/06110245.pdf, hlm. 48.

53 Sukardi, Metodologi Penelitian Pendidikan, Jakata: Bumi Aksara, 2009, hlm. 4

54Lihat juga http://www.kompasiana.com/nararyanggadas/istilah-library-research-dalamkarya-tulis-ilmiah-tepat 54f74265a33311b2708b4829. Dikutip pada hari Selasa, 21 Juli 2015.

55 Lebih rincinya lihat Nana Syaodih Sukmadinata, Metode Penelitian Pendidikan, hlm. 12. 
56Lihat juga http://www.kompasiana.com/nararyanggadas/istilah-library-research-dalamkarya-tulis-ilmiah-tepat_54f74265a33311b2708b4829.

57https://hidrosita.wordpress.com/2013/02/17/contoh-proposal-library-research/. Dikutip pada hari Selasa, 21 Juli 2015.

58 https://hidrosita.wordpress.com/2013/02/17/contoh-proposal-library-research/. Dikutip pada hari Selasa, 21 Juli 2015.

59http://kbbi.web.id/implementasi.,http://www.artikata.com/arti-330542implementasi.html., https://id.wiktionary.org/wiki/implementasi. Dikutip pada hari Rabu, 17 Juni 2015.

60 Lihat juga http://elib.unikom.ac.id/files/disk1/487/jbptunikompp-gdl-derrisepti-24335-2babii d-x.pdf. Dikutip pada hari Rabu, 17 Juni 2015.

61 Ahmad Tafsir, Filsafat Pendidikan Islami, Bandung: Rosda, cetakan keempat, 2010, hlm. 76

62 Ibid, hlm. 80.

63 Ibid, hlm. 81

64 'Iyâd Abdul Hamîd 'Aql, Gaza: Ma'âlim at Tarbiyah al Jihâdiyah min Khilâl Kitâbât Abdillâh 'Azzâm, hlm. 62., Shafwat Samîr al Buhairî, At Tarbiyah min Khilâl Ghazâwât ar Rasûl S.A.W, hlm. 22.

65 Salah satu artikel yang bisa dijadikan referensi lihat: http://www.alseraj.net/maktaba/ kotob/duaa/nazrat/maktaba_fkreia/book03/5.htm

66 Ahmad Tafsir, Filsafat Pendidikan Islami, 79

67Untuk lebih ricinya lihat Ahmad Tafsir, Ilmu Pendidikan Islami, hlm. 57-60. Dalam menjelaskan ciri jasmani yang sehat dan kuat, Ahmad Tafsir menyatakan, "Sehat, kuat dan berketerampilan". Lihat Ahmad Tafsir, Ilmu Pendidikan Islami, hlm. 70.

68 Untuk lebih lengkapnya lihat Ahmad Tafsir, Ilmu Pendidikan Islami, hlm. 75 dan 77

69 Abdullah al Jibrin, Tahdzîb Tabsîth al Aqîdah al Islâmiyah, Riyad: Maktabah Malik Fahd, 1425H, hlm. 26

70 Ibn al Jauzi, Bustanul Wâ'idzîn wa Riyadhu as Sâmi'în, Beirut: Mu'assasatul Kutub al Tsaqafiyah, 1998, hlm. 151. Tema seputar semangat dan antusias dalam jihad pernah diangkat di Universitas Gaza Fakultas Sains dan Tekhnologi dengan pemateri Ribhi Judaili, pada Jumat, $30 \quad$ November $2012, \quad$ lihat http://www.maannews.net/Content.aspx?id=543637.

71 Muslim, Shahih Muslim, Beirut: Dar Ihya at Turats al 'Arabi, tanpa tahun, 4/2004, hadits no. 2594

72 Ahmad Tafsir, Filsafat Pendidikan Islami, hlm. 167

73 Muslim bin Hajjaj, Shahih Muslim, Beirut: Dar Ihya at Turats al 'Arabi, tanpa tahun, vol. II, hlm. 789, hadits no. 1120.

74 Kecuali tempat-tempat yang ada larangan membacanya seperti di kandang unta dan tempat buang hajat

75 Baghawi, Syarh as Sunnah, Beirut: al Maktab al Islami, 1983, vol. 1, hlm. 209

76 Ibn Hajar al 'Asqalânî, Fath al Bârî, vol. VI, hlm. 62, hadits no. 2842

77 Abdul Majid, Strategi Pembelajaran, Bandung: Rosda, 2014, hlm. 27-28

78 http://jurnal.upi.edu/file/02 Pengaruh Penerapan Metode Targb Tarhb - Rani.pdf. dikutip Rabu, 24 Juni 2015.

79Khâlid al- Hâzimî, Ushûl at Tarbiyah al Islâmiyah, Madinah Munawwarah: Dâr 'Âlamil Kutub, 2000, hlm. 395

80 Ahmad Tafsir, Ilmu Pendidikan Islami, 210-211

81Ahmad Dhaifullâh Umar, Al Malâmih at Tarbiyah al Jihâdiyah wa Tathbîqâtuhâ at Tarbawiyah, Gaza: Jami'ah Islamiyah, 2010, hlm. 126

82Khâlid al- Hâzimî, Ushûl at Tarbiyah al Islâmiyah, hlm. 402

83 Ahmad Tafsir, Ilmu Pendidikan Islami, hlm. 221

84 Ahmad Tafsir, Ilmu Pendidikan Islami, hlm. 202.

85 http://febri2289.blogspot.com/2010/02/pendidikan-berbasis-cinta-dan-kasih.html

86 Abdul Majid, Strategi Pembelajaran, hlm. 210 
87 Lihat Abdul Majid, Strategi Pembelajaran, 195-196.

88Ali Zahrani, al Asâlib at Ta'limiyah al Mustaqâh min Khilâl Tarâjimil Imâm al Bukhârî 'alâ Ahadits Kitâb al 'Ilm fí Jâmi'ihi as Shahîh, PDF, hlm. 436

89 Ibid, hlm. 432

90 Ahmad Tafsir, Ilmu Pendidikan Islami, hlm. 210.

91 Khâlid al- Hâzimî, Ushûl at Tarbiyah al Islâmiyah, hlm. 377-378

92 Ibid, hlm. 390

93 Lihat Abdul Majid, Strategi Pemebelajaran, 208-209

94 Ahmad Tafsir, Ilmu Pendidikan Islami, hlm. 212. Lihat juga Khâlid al- Hâzimî, Ushûl at Tarbiyah al Islâmiyah, hlm. 377-378.

95 Ahmad Tafsir, Filsafat Pendidikan Islami, hlm. 230

96Ahmad Tafsir, Ilmu Pendidikan Islami, hlm. 213.

97 Abdu Majid, Strategi Belajar, hlm. 211.

98 Seminar ini diselenggarakan pada hari Sabtu, 11 Juni 2015 bertempat di Aula SMK al Irsyad kota Tegal

99 Ali Zahrani, al Asâlib at Ta'limiyah, hlm. 427-428

100 Ibid, hlm. 440-441

101 Khâlid al- Hâzimî, Ushûl at Tarbiyah al Islâmiyah, hlm. 377-378

102 Lihat Ahmad Tafsir, Ilmu Pendidikan Islami, 215

103 Ibid, hlm. 217.

104 http://www.suaramerdeka.com/v1/index.php/read/cetak/2014/07/16/267537/KurangMurid-Sekolah-Digabung. Dikutip pada hari Sabtu, 4 Juli 2015.

105 http://metro.tempo.co/read/news/2015/04/23/064660256/pesta-bikini-ahok-pelajarsma-yang-ikut-kena-sanksi. Dikutip pada hari Sabtu, 4 Juli 2015.

106 http://www.unpad.ac.id/pembelajaran/evaluasi-hasil-belajar-dan-batas-waktustudi/evaluasi-hasil-belajar/. Dikutip pada hari Sabtu, 4 Juli 2015.

107 Ibid.

108 http://krjogja.com/read/174949/tingkat-kelulusan-smpmts-di-sukoharjo-naik-9967-.kr. Dikutip pada hari Sabtu, 4 Juli 2015.

109 https://murniramli.wordpress.com/2009/01/05/kebijakan-evaluasi-guru-di-jepang/. Dikutip pada hari Sabtu, 4 Juli 2015 